\title{
Effect of Fertilization and Rootstocks Type on Vegetative Growth and Nutritional Status of Crimson Grapevine Transplants

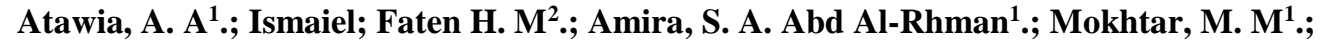 \\ 1- Hort. Dept. Fac. of Agric. Benha University. Egypt \\ 2-Botany. Dept. Fac. of Agric. Benha University. Egypt
}

\begin{abstract}
This study was carried out during both 2018 and 2019 experimental seasons to cover the influence of the two investigated factors i.e., rootstock grape type (Freedom and Richter) and some bio-stimulants compounds (compost, Bacillus polymyxa, EM and Azotobacter chrococcum) and their possible combinations. The influence was evaluated through the response of some vegetative growth and nutritional status of the treated "Crimson" grape cultivar. The specific effect of rootstock type on vegetative growth, data revealed that, Freedom rootstock was better than the other investigated rootstock (Richter) in this respect. Also, fertilizer with T4 and T5 g/transplant were superiors in this respect whereas able to they were increase significantly vegetative growth as compared with the other different investigated fertilization during both 2018 and 2019 seasons of study. Considering the interaction effect of the two investigated factors i.e., rootstock type and different bio-stimulants (compost, Bacillus polymyxa, EM and Azotobacter chrococcum) on vegetative growth of grape transplants, data show the highest value of vegetative growth were obtained with the combination between Crimson grape transplants grafted on Freedom rootstock and fertilized with T4, T5 and T7 g/transplants. The obtained results clearly show that, all treatments increased nutritional status for both rootstocks (Freedom and Richter) of grapevine (Vitis vinifera L.) in leaves as compared with control treatment.
\end{abstract}

Keywords: Freedom, Richter, grape, vegetative growth, nutritional status, compost, Bacillus polymyxa, Azotobacter chrococcum and Effective micro-organisms.

\section{Introduction}

Grape is the common name for any of the woody, vining plants belonging to the about 60 species comprising the genus Vitis in the flowering plant family Vitaceae. It is also the name for the edible fruit that grows on these perennial and deciduous plants. Some consider grape a common term for all members of the family vitaceae. The grape can be eaten row or used for making Jam, Juice, Jelly wine and grape seed oil, for being of an excellent flavor, nice taste and high nutritional value (Hulme, 1971).

Grape cultivation began in Asia Minor which considers the home of Vitis vinifera from which all the cultivated grape varieties were derived before the discovery of North America (Winkler, 1965).

Grape (Vitis vinifera) is considered the first major fruit crop in the production all over the world. In Egypt, grapes ranked the third among fruit crops while citrus being the first and mango the second. The total acreage of grapevines in Egypt exhibited an obvious increase in the recent years till it reached about 188000 feddans with production of 1531418 tons according to the latest Statistics of Ministry of Agriculture (2019). The area dedicated to vineyards is increasing by about $2 \%$ yearly.

Fertilization is one of the important tools in increasing crop yield. Nitrogen has a pronounced role in improving production and quality of fruits. The efficiency of nitrogen fertilizers under field conditions and surface irrigated soil rarely exceeds $5 \%$ and is usually ranged between 30 and $40 \%$ (Sahrawat, 1979). Such low efficiency may be due to losses of $N$ from soils as nitrate and nitrate by leaching or as nitrogen gases through nitrate reduction by volatilization. Leaching of nitrate and its down ward movement below the root zone with the flowing water cause may problems such as nitrate pollution of ground water and growing crops. The free nitrogen fixation bacteria such as Azotobacter chroococcum and Azspirillum sp. can be used as a bio fertilizer to provide some nitrogen requirements to agriculture plants. This method of fertilization was tested to know how much nitrogen and possibly other nutrients can be affected by this bio fertilizer. In this respect, researchers with bio fertilization indicated that this method affect nutrient content in treated plants (Mahmoud and Mahmoud, 1999).

Phosphorus is very important nutrient for crop growth and high yield with good quality. It is play a key role in metabolic process such as the conversion of sugar into starch and cellulose. As a result, phosphorus deficiency causes stunting, delayed maturity and shriveled seeds. In sandy soils, some nutrient problems such as less fertility in general and less a viability of some elements such as phosphorus in case of high $\mathrm{PH}$ value can affect plant production. In the context, yield and its components showed a positive response to phosphorus fertilizers. $\mathrm{P}$ applications have increased flower formation (Chatzatheodorou et al., 2004).

Potassium has a considerable role in improving production and quality of fruit. Potassium had a pertinent role in many metabolic processes, such as carbohydrate synthesis and development of meristematic tissue, as well as encouragements of 
lignification and regulation of water absorption and transpiration (Mengel and Ameke, 1982).

Nowadays, bio fertilization of various grapevines cvs. has called the attention of research workers as an alternative to chemical fertilizers. Bio-fertilization is very safe for human, animal and environment to get lower pollution and reduced soil salinity via decrease using mineral fertilization as well as saving fertilization costs. Bio-fertilizers mainly comprise nitrogen fixers such as Rhizobium, Azotobacter, Phosphate dissolves or VAM and silicate bacteria (Idso et al., 1995).

Bio-fertilizers are the most importance for plant production and soil as they play in important role in increasing vegetative growth (Fayed, 2005b) on apple. Also, Hassan and Abou-Rayya (2003) showed that, all bio-fertilizers (Compost, BC, EM and $\mathrm{Az}$ ) were effective in improving nutritional status of Anna apple trees.

The main objective of this study is to carry out a using bio fertilizers (Compost, BC, and $\mathrm{Az}$ ) and organic fertilizer (EM) to improve growth of Crimson transplants grafted on two rootstocks (Freedom and Richter) which grown in sandy loam soil.

\section{Materials And Methods}

The present investigation was undertaken throughout the two successive seasons of 2018 and 2019 at Fruit Nursery of Horticulture Department, Faculty of Agriculture at Moshtohor, Benha University Qalyubeia Governorate, Egypt.

Uniform and healthy one-year- old transplants of Crimson cv. grafted on Freedom and Richter rootstocks grape "Vitis vinifera, L." were the plant material used in this study. In both seasons of study and during the first week of February, these transplants were planted individually each in plastic pot of 30-cm-diameter filled with about $3.5 \mathrm{~kg}$ of sand and loam mixture at equal parts by volume.

Before the experiment had been conducted in the two seasons, both mechanical and chemical analyses of growing medium were done as shown in Table (1). The physical and chemical properties analysis according to Jackson (1967).

Table 1. The physical and chemical analysis of the used sand and loam during two seasons.

\begin{tabular}{|c|c|c|c|c|c|c|c|c|c|c|c|c|c|}
\hline \multirow[b]{2}{*}{ Soil type } & \multicolumn{4}{|c|}{ Particle size distribution (\%): } & \multirow[b]{2}{*}{$\begin{array}{c}\text { E.C. } \\
\text { (dS/m) }\end{array}$} & \multirow[b]{2}{*}{$\mathrm{pH}$} & \multicolumn{4}{|c|}{ Cations (meq/L) } & \multicolumn{3}{|c|}{ Anions (meq/L) } \\
\hline & $\begin{array}{c}\text { Coarse } \\
\text { sand }\end{array}$ & $\begin{array}{l}\text { Fine } \\
\text { Sand }\end{array}$ & Silt & Clay & & & $\mathrm{Ca}^{++}$ & $\mathrm{Mg}^{++}$ & $\mathrm{Na}^{+}$ & $\mathrm{K}^{+}$ & $\mathrm{HCO}_{3}^{-}$ & $\mathrm{Cl}^{-}$ & $\mathrm{SO}_{4}^{--}$ \\
\hline \multirow{2}{*}{ Sand } & 89.03 & 2.05 & 0.40 & 8.52 & 3.72 & 7.92 & 7.50 & 1.63 & 33.60 & 0.50 & 3.20 & 22.00 & 18.03 \\
\hline & 90.10 & 1.95 & 0.50 & 7.45 & 3.74 & 7.80 & 19.42 & 8.33 & 7.20 & 0 . & 1.60 & 7.00 & 27.10 \\
\hline \multirow{2}{*}{ Loam } & 10.18 & 46.17 & 19.53 & 24.12 & 3.38 & 8.09 & 17.50 & 9.42 & 20.00 & 0.79 & 3.80 & 10.00 & 33.91 \\
\hline & 10.30 & 46.54 & 18.88 & 24.28 & 3.51 & 8.16 & 18.00 & 8.95 & 20.50 & 0.85 & 3.65 & 10.20 & 34.45 \\
\hline
\end{tabular}

The bio-fertilizer (BF) used in this study were produced by Ministry of Agriculture. This experiment involved seven treatments:

1) Mineral NPK fertilization program as control (recommended doses "R.D." was annually (8,6,4 gm) in three doses for each dose from ammonium sulphate $(20.6 \% \mathrm{~N})$, super phosphate $\left(15.5 \% \mathrm{P}_{2} \mathrm{O}_{5}\right)$ and potassium sulphate $\left(48.0 \% \mathrm{~K}_{2} \mathrm{O}\right)$, respectively.

2) $50 \% \operatorname{NPK}(4,3,2 \mathrm{~g})+25 \mathrm{~g}$ compost.

3) $50 \% \mathrm{NPK}(4,3,2 \mathrm{~g})+50 \mathrm{~g}$ compost.

4) $50 \% \mathrm{NPK}(4,3,2 \mathrm{~g})+75 \mathrm{~g}$ compost.

5) $50 \%$ NPK $(4,3,2 \mathrm{~g})+25 \mathrm{~g}$ compost $+10 \mathrm{~cm}$ bio fertilizer (BC).

6) $50 \%$ NPK $(4,3,2 \mathrm{~g})+50 \mathrm{~g}$ compost $+10 \mathrm{~cm}$ bio fertilizer (EM).

7) $50 \%$ NPK $(4,3,2 \mathrm{~g})+75 \mathrm{~g}$ compost $+10 \mathrm{~cm}$ bio fertilizer (AZ).

The corresponding amount of each fertilizer treatment was fractionated into three equal doses to be soil applied from mid-March, mid-May and mid-July during both seasons. Whereas, the treatments were arranged in a randomized complete block design with three replicated for each treatment however, each replicate was represented by four grape transplants. On the first week of October during both seasons of study as an experiment was ended. The effect of the different investigated treatments on some vegetative growth measurements and chemical composition were evaluated by the following growth parameters during both seasons as follows:

\section{a. Vegetative growth measurements:}

An influence of different treatments in this study on some vegetative growth parameters were evaluated through determining the following:

Stem length $(\mathrm{cm}$.$) ; stem diameter (\mathrm{cm})$; No. of leaves/plant; No. of lateral shoots, leaf area $\left(\mathrm{cm}^{2}\right)$; root length $(\mathrm{cm})$; total weights of fresh and dry plant organs (gm).

On mid-August during both seasons, samples of forty mature leaves at different four sides of each tree were collected by picking the third one from the base of the previously labeled shoots and leaf area was determined. Length and width of lamina of these leaves were measured to find out the average leaf area in spring growth cycle by using of equation of Chou (1966).

Leaf area $\left(\mathrm{cm}^{2}\right)=2 / 3$ (leaf length $\mathrm{x}$ leaf width).

b. Chemical analysis:

- Leaf chlorophyll content:

An average of twenty eight chlorophyll metter reading for each treatment were recorded by using a 
portable chlorophyll metter spad 502 according to Wood et al., (1992).

\section{- Leaf mineral determination:}

Ten full expanded leaves were carefully collected in the second week of August in both seasons of this study from all directions of every transplant canopy, which seemed to be sufficient for giving a reasonable good representation of the transplant. The leaves were taken from third to fifth leaf from the base shoots to preparation for chemical analysis.

As soon as, the leaf samples, were picked, then cleaning with damp cloth to remove any residues that might effect the results Labanauskas (1966), therefore fresh weight was determined and oven dried in a ventilated oven at $70{ }^{\circ} \mathrm{C}$ till a constant weight, then weighed and ground with porcelain mortar and pistle, after being ground, the samples were stored in small paper bags until used for the determination of $\mathrm{N}$; $\mathrm{P} ; \mathrm{K} ; \mathrm{Mg} ; \mathrm{Fe} ; \mathrm{Zn}$ and $\mathrm{Mn}$ samples of $0.2 \mathrm{gm}$ dried material were dissolved in $5 \mathrm{ml}$ concentrated sulphoric acid. After being cold $2 \mathrm{ml}$ of the digesting mixture (1 $: 1$ perchloric acid : sulphoric acid) were added then samples were reheated for clearing, then cooled and disputed with deionized water before it had been transformed quantitatively to $50 \mathrm{ml}$ volume with deionized water (Piper 1958). The contents were used for the following determinations.

- Nitrogen content $(\%)$ :

Total nitrogen was determined by the modified micro-Kjeldahl method as described by Pregl (1945).

- Phosphorus content (\%):

Total phosphorus content was determined using a Spekol spectrophotometer at 882.0 U.V. according to the method described by Murphy and Riely (1962).

- K; Ca; Mg; Fe; Zn and Mn contents:

Leaf $\mathrm{K}$; $\mathrm{Ca} ; \mathrm{Mg}$; $\mathrm{Fe}$; $\mathrm{Zn}$ and $\mathrm{Mn}$ contents were determined by using the Atomic Absorption Spectrophotometer (3300) according to Jackson and Ulrich (1959) and Chapman and Pratt (1975). Leaf nutrient element contents were expressed as a ratio of the dry weight i.e., percentage for the macro-elements $(\mathrm{N} ; \mathrm{P} ; \mathrm{K}$ and $\mathrm{Mg}$ ) and part per million (ppm) with micro-nutrient (Fe; $\mathrm{Zn}$ and $\mathrm{Mn}$ ).

\section{- Statistical analysis:}

All the obtained data in the two seasons of study were statistically analyzed using the analysis of variance method according to Snedecor and Cochran (1988). However, means were distinguished by the Duncan's multiple range test (Duncan, 1955). Since, capital letters were used for distinguishing means within each column or row that represented the specific effect of any investigated factor, however, the small letters were employed for interaction effect of their combinations.

\section{Results and Discussion}

This investigation was carried out to cover the influence of the two investigated factors namely: 1rootstock grape type (Freedom and Richter), 2- some bio-stimulants compounds (Compost, BC, Az and EM) and their possible combinations on "Crimson" transplants were studied during both 2018 and 2019 seasons. Such influence was evaluated through the response of some vegetative growth and anatomical measurements of the treated "Crimson" grape cultivar.

Therefore, obtained results presented in Tables (2, $3,4,5,6,7,8$ and 9) in this study dealing with any of the abovementioned three aspects are separately during both seasons of study discussed as follows:

\section{- Stem length $(\mathrm{cm})$}

\section{A. Specific effect:}

Regarding to the specific effect of rootstock type on stem length $(\mathrm{cm})$ data presented in Table (2) cleared obviously that, Freedom rootstock was better than the other investigated rootstock (Richter) in this respect. Concerning the specific effect of the different biostimulants (Compost, BC, EM, and Az) on Crimson grape stem length $(\mathrm{cm})$, data represented in Table (2) mentioned that, fertilization with (T5) $50 \%$ of control at rate $(4,3,2)$ plus $25 \mathrm{~g}$ compost and $10 \mathrm{~cm}$ bio fertilizer (BC) $\mathrm{g} /$ transplant was superior in this respect where it was able to increase significantly stem length $(\mathrm{cm})$ as compared with the different investigated fertilization (Compost, BC, EM, and Az) during both 2018 and 2019 seasons of study. Fertilization with (T4) $50 \%$ of control at rate $(4,3,2)+75 \mathrm{~g}$ compost and EM at 10 /transplants came in the second rank, we can concluded that, there was positive relationship between stem length of increment crimson grape transplants and amount of fertilizer.

\section{B. Interaction effect:}

Concerning the interaction effect of the two investigated factors i.e., rootstock type and different bio-stimulant (Compost, BC, EM, and Az) on grape transplants stem length $(\mathrm{cm})$, data in Table (3) declared that a considerable and statistically effect in two seasons of the study, where the highest stem length was obtained with the combination between Crimson grape transplants grafted on Freedom rootstock and fertilized with T5 (50\% control at rate $(4,3$, 2) $+25 \mathrm{~g}$ compost $+10 \mathrm{~cm}$ bio fertilizer (BC) $\mathrm{g} /$ transplants, however the lowest value in stem diameter was noticed by Crimson grape grafted on Richter rootstock and fertilizer with mineral element (control) during the two seasons of study.

This results is agreement with that reported by Mahmoud and Mahmoud (1999) and El-Akkad (2004). 
Table 2. Effect of mineral and bio-organic fertilizers on stem length $(\mathrm{cm})$ of Crimson grape transplants grafted on both Freedom and Richter rootstocks during both 2018 and 2019 seasons.

\begin{tabular}{|c|c|c|c|c|c|c|}
\hline \multirow{3}{*}{ Treatments } & \multicolumn{6}{|c|}{ Stem length $(\mathrm{cm})$} \\
\hline & Freedom & Richter & Mean** & Freedom & Richter & Mean** \\
\hline & \multicolumn{3}{|c|}{ First season; 2018} & \multicolumn{3}{|c|}{ Second season; 2019} \\
\hline T1. Control (R.D) NPK at rate $(8,6,4 \mathrm{~g})$. & $83.00 \mathrm{~h}$ & $89.17 \mathrm{f}$ & 86.08C & $87.50 \mathrm{fg}$ & $81.17 \mathrm{~h}$ & 84.33E \\
\hline $\mathrm{T} 2.50 \%$ control at rate $(4,3,2)+25 \mathrm{~g}$ compost. & $90.33 \mathrm{ef}$ & $69.33 \mathrm{i}$ & 79.83D & $88.00 \mathrm{ef}$ & $87.00 f g$ & 87.50D \\
\hline T3. $50 \%$ control at rate $(4,3,2)+50 \mathrm{~g}$ compost. & $89.33 f$ & $93.00 \mathrm{~d}$ & 91.17B & $91.50 \mathrm{~d}$ & $86.33 \mathrm{~g}$ & 88.92C \\
\hline $\mathrm{T} 4.50 \%$ control at rate $(4,3,2)+75$ g compost. & $94.00 \mathrm{~cd}$ & $95.00 \mathrm{c}$ & $94.50 \mathrm{~A}$ & $94.33 c$ & $92.00 \mathrm{~d}$ & 93.17B \\
\hline $\begin{array}{l}\text { T5. } 50 \% \text { control at rate }(4,3,2)+25 \text { g compost }+10 \\
\text { cm bio fertilizer }(\mathrm{BC}) .\end{array}$ & $103.0 \mathrm{a}$ & $87.33 \mathrm{~g}$ & 95.17A & $100.7 \mathrm{a}$ & $88.33 \mathrm{ef}$ & 94.50A \\
\hline $\begin{array}{l}\text { T6. } 50 \% \text { control at rate }(4,3,2)+50 \text { g compost }+10 \\
\text { cm bio fertilizer }(\mathrm{EM}) .\end{array}$ & $91.00 \mathrm{e}$ & $69.67 \mathrm{i}$ & 80.33D & $87.00 \mathrm{fg}$ & $88.00 \mathrm{ef}$ & 87.50D \\
\hline $\begin{array}{l}\text { T7. } 50 \% \text { control at rate }(4,3,2)+75 \text { g compost }+10 \\
\text { cm bio fertilizer (AZ). }\end{array}$ & $91.33 \mathrm{e}$ & $98.00 \mathrm{~b}$ & 94.67A & $96.00 \mathrm{~b}$ & $89.00 \mathrm{e}$ & 92.50B \\
\hline Mean* & $91.71 \mathrm{~A}$ & 85.93B & & 92.15A & 87.40B & \\
\hline
\end{tabular}

\section{- Stem diameter (cm).}

\section{A. Specific effect:}

Referring the specific effect of rootstock type on stem diameter $(\mathrm{cm})$ data presented in Table (3) obviously that, Freedom rootstock was better than the other investigated rootstock (Richter) in this respect. Concerning the specific effect of the different biostimulants (Compost, BC, EM, and Az) on Crimson grape stem diameter, data presented in Table (3) revealed that, fertilization with both $\mathrm{T} 3$ and $\mathrm{T} 7$ were superiors treatments in this concern during both 2018 and 2019 seasons. (T3) $50 \mathrm{~g}$ compost g/transplant combined with mineral NPK at $50 \%$ R.D. was superior in this respect where they were able to increase significantly stem diameter $(\mathrm{cm})$ as compared with the different investigated fertilization (Compost, BC, EM, and Az) during both 2018 and 2019 seasons. Fertilization with (T4) $75 \mathrm{~g}$ compost mineral NPK at $50 \%$ R.D./transplants came in the second rank with non-significant in first season only. Also, there was a positive relation between stem diameter of increment crimson grape transplants and amount of fertilizer.

Table 3. Effect of mineral and bio-organic fertilizers on stem diameter $(\mathrm{cm})$ of Crimson grape transplants grafted on both Freedom and Richter rootstocks during both 2018 and 2019 seasons.

\begin{tabular}{|c|c|c|c|c|c|c|}
\hline Parameter & \multicolumn{6}{|c|}{ Stem diameter $(\mathrm{cm})$} \\
\hline Rootstocks & Freedom & Richter & Mean** & Freedom & Richter & Mean** \\
\hline & \multicolumn{3}{|c|}{ First season; 2018} & \multicolumn{3}{|c|}{ Second season; 2019} \\
\hline T1. Control (R.D) NPK at rate $(8,6,4 \mathrm{~g})$. & $0.880 \mathrm{~d}$ & $0.840 \mathrm{e}$ & $0.860 \mathrm{C}$ & $0.850 \mathrm{~g}$ & $0.800 \mathrm{~h}$ & $0.825 \mathrm{D}$ \\
\hline $\mathrm{T} 2.50 \%$ control at rate $(4,3,2)+25 \mathrm{~g}$ compost. & $0.767 f$ & $0.740 \mathrm{~g}$ & $0.753 \mathrm{D}$ & $0.760 \mathrm{i}$ & $0.730 \mathrm{j}$ & $0.745 \mathrm{E}$ \\
\hline T3. $50 \%$ control at rate $(4,3,2)+50$ g compost. & $1.080 \mathrm{a}$ & $0.940 \mathrm{~b}$ & $1.010 \mathrm{~A}$ & $1.050 \mathrm{c}$ & $0.930 \mathrm{e}$ & 0.990B \\
\hline $\mathrm{T} 4.50 \%$ control at rate $(4,3,2)+75 \mathrm{~g}$ compost. & $1.080 \mathrm{a}$ & $0.920 \mathrm{c}$ & $1.000 \mathrm{AB}$ & $1.100 \mathrm{~b}$ & $0.910 \mathrm{ef}$ & $1.005 \mathrm{~B}$ \\
\hline $\begin{array}{l}\text { T5. } 50 \% \text { control at rate }(4,3,2)+25 \text { g compost }+10 \\
\text { cm bio fertilizer (BC). }\end{array}$ & $0.780 \mathrm{f}$ & $0.950 \mathrm{~b}$ & $0.865 \mathrm{C}$ & $0.750 \mathrm{ij}$ & $0.960 \mathrm{~d}$ & $0.855 \mathrm{C}$ \\
\hline $\begin{array}{l}\text { T6. } 50 \% \text { control at rate }(4,3,2)+50 \mathrm{~g} \text { compost }+10 \\
\mathrm{~cm} \text { bio fertilizer }(\mathrm{EM}) .\end{array}$ & $0.780 f$ & $0.940 \mathrm{~b}$ & $0.860 \mathrm{C}$ & $0.770 \mathrm{i}$ & $0.890 f$ & $0.830 \mathrm{D}$ \\
\hline $\begin{array}{l}\text { T7. } 50 \% \text { control at rate }(4,3,2)+75 \mathrm{~g} \text { compost }+10 \\
\mathrm{~cm} \text { bio fertilizer (AZ). }\end{array}$ & $1.080 \mathrm{a}$ & $0.910 \mathrm{c}$ & $0.995 \mathrm{~B}$ & $1.153 \mathrm{a}$ & $0.900 f$ & $1.027 \mathrm{~A}$ \\
\hline Mean* & $0.921 \mathrm{~A}$ & $0.891 \mathrm{~B}$ & & $0.919 \mathrm{~A}$ & $0.874 \mathrm{~B}$ & \\
\hline
\end{tabular}

* and ** means refer to specific effect of root stock type and different treatments of bio-stimulants soil applied, respectively. Values within the same column or row for any of two investigated factors followed by the same letter/s were not significantly at $5 \%$ level where capital letter/s, were used for distinguishing specific effect value of each investigated factor but small letters for interaction of their combination.

\section{B. Interaction effect:}

Considering the interaction effect of the two investigated factors i.e., rootstock type and different bio-stimulant (Compost, BC, EM, and Az) on grape transplants stem diameter $(\mathrm{cm})$, data tabulated in Table (3) reported that a considerable and statistically 
effect in both seasons of the study, where the highest stem diameter was obtained with the combination between Crimson grape transplants grafted on Freedom rootstock and fertilized with $50 \mathrm{~g}$ compost plus $50 \%$ R.D. NPK /transplants, while the lowest value in stem diameter was noticed by Crimson grape grafted on Richter rootstock and fertilizer with T2 $50 \%$ R.D. NPK plus $25 \mathrm{~g}$ compost with Richtet transplant during the two seasons of study.

This results is agreement with that reported by Mahmoud and Mahmoud (1999); El-Akkad (2004); Ahmed-Ebtsam and Abd El Aal et al., (2019).

\section{- Number of leaves.}

Concerning the specific effect of the two investigated factors i.e., rootstock type (Freedom and Richter) and the different fertilization treatments on number of leaves of Crimson grape, number of leaves of the two investigated rootstocks (Freedom and Richter), data presented in Table (4) indicated that Freedom rootstock gave the highest values of the investigated parameter (number of leaves) as compared with the other investigated rootstock (Richter) during both seasons of study.

Regarding the specific effect of different fertilization treatments (Compost, BC, EM and $\mathrm{Az}$ ) on number of leaves, data presented in Table (4) revealed that, the investigated parameter took the dissimilar trend where their values were significantly increased when the transplants were fertilized with both ("T4" 50\% R.D. and $\mathrm{T} 7$ mineral NPK $+75 \mathrm{~g}$ compost) in the first season and ("T7" 50\% R.D. mineral NPK at rate $(4,3,2)+75 \mathrm{~g}$ compost $+10 \mathrm{~cm}$ bio fertilizer (AZ) at $\mathrm{g} /$ transplant) in the second one, respectively for number of leaves per transplant.

\section{B. Interaction effect:}

Concerning the interaction between rootstock type (Freedom and Richter grapevine) and different biofertilizers (Compost, BC, EM and Az) on number of leaves per transplant, data are recorded in Table (4) it is quite clear from data that, the best result in significantly regarding number of leaves was obtained with Freedom grape rootstock combined with fertilized with rate Compost at $25+10 \mathrm{~cm}$ bio-fertilizer (BC) g/ transplant in the two seasons, respectively. The combination between Richter grapevine rootstock with control treatment had the lowest effect regarding number of leaves during both seasons of study.

The present result is in harmony with those found by Mostafa (2008) and Seleem-Basma and Telep (2008); Ahmed-Ebtsam (2008) and Abd El Aal et al., (2019).

Table 4. Effect of mineral and bio-organic fertilizers on No. of leaves/plant of Crimson grape transplants grafted on both Freedom and Richter rootstocks during both 2018 and 2019 seasons.

\begin{tabular}{|c|c|c|c|c|c|c|}
\hline Parameter & \multicolumn{6}{|c|}{ No. leaves/transplant } \\
\hline Rootstocks & Freedom & Richter & Mean** & Freedom & Richter & Mean** \\
\hline & \multicolumn{3}{|c|}{ First season; 2018} & \multicolumn{3}{|c|}{ Second season; 2019} \\
\hline T1. Control (R.D) NPK at rate $(8,6,4 \mathrm{~g})$. & $26.00 f$ & $28.00 \mathrm{e}$ & 27.00E & $22.00 \mathrm{~h}$ & $26.00 \mathrm{~g}$ & 24.00F \\
\hline $\mathrm{T} 2.50 \%$ control at rate $(4,3,2)+25 \mathrm{~g}$ compost. & $34.00 \mathrm{c}$ & $34.00 \mathrm{c}$ & 34.00B & $32.00 \mathrm{e}$ & $35.00 \mathrm{~d}$ & $33.50 \mathrm{C}$ \\
\hline $\mathrm{T} 3.50 \%$ control at rate $(4,3,2)+50 \mathrm{~g}$ compost. & $31.00 \mathrm{~d}$ & $31.00 \mathrm{~d}$ & 31.00C & $31.3 \mathrm{e}$ & $30.00 \mathrm{f}$ & 30.67D \\
\hline $\mathrm{T} 4.50 \%$ control at rate $(4,3,2)+75 \mathrm{~g}$ compost. & $38.00 \mathrm{~b}$ & $37.00 \mathrm{~b}$ & 37.50A & $36.00 \mathrm{~d}$ & $38.00 \mathrm{c}$ & 37.00B \\
\hline $\begin{array}{l}\text { T5. } 50 \% \text { control at rate }(4,3,2)+25 \mathrm{~g} \text { compost }+ \\
10 \mathrm{~cm} \text { bio fertilizer }(\mathrm{BC}) .\end{array}$ & $41.00 \mathrm{a}$ & $19.00 \mathrm{~g}$ & 30.00D & $45.00 \mathrm{a}$ & $22.00 \mathrm{~h}$ & 33.50C \\
\hline $\begin{array}{l}\text { T6. } 50 \% \text { control at rate }(4,3,2)+50 \mathrm{~g} \text { compost }+ \\
10 \mathrm{~cm} \text { bio fertilizer }(\mathrm{EM}) .\end{array}$ & $26.00 \mathrm{f}$ & $27.00 \mathrm{ef}$ & $26.50 \mathrm{E}$ & $25.00 \mathrm{~g}$ & $26.00 \mathrm{~g}$ & $25.50 \mathrm{E}$ \\
\hline $\begin{array}{l}\text { T7. } 50 \% \text { control at rate }(4,3,2)+75 \mathrm{~g} \text { compost }+ \\
10 \mathrm{~cm} \text { bio fertilizer }(\mathrm{AZ}) .\end{array}$ & $41.00 \mathrm{a}$ & $35.00 \mathrm{c}$ & 38.00A & $36.00 \mathrm{~d}$ & $42.00 \mathrm{~b}$ & 39.00A \\
\hline Mean* & 33.86A & 30.14B & & $32.48 \mathrm{~A}$ & 31.29B & \\
\hline
\end{tabular}

* and ** means refer to specific effect of root stock type and different treatments of bio-stimulants soil applied, respectively. Values within the same column or row for any of two investigated factors followed by the same letter/s were not significantly at $5 \%$ level where capital letter/s, were used for distinguishing specific effect value of each investigated factor but small letters for interaction of their combination.

\section{- No. of lateral shoot.}

Concerning the specific effect of the two investigated factors i.e., rootstock type (Freedom and Richter) and the different fertilization treatments on No. of lateral shoot of Crimson grape, No. of lateral shoot of the two investigated rootstocks (Freedom and Richter), data tabulated in Table (5) indicated that Freedom rootstock gave the highest values of the investigated parameter (No. of lateral shoot) as compared with the other investigated rootstock (Richter) during the two seasons of study.

Referring the specific effect of different fertilization treatments (Compost, BC, EM and Az) on No. of lateral shoot, data in Table (5) obvious that, the investigated parameter took the dissimilar trend where their values were significantly increased when the transplants were fertilized with ("T4"; "T5" and "T7") and ("T5" and "T7" at g/ transplant) during both 
seasons, respectively for No. of lateral shoot per transplant.

\section{B. Interaction effect:}

Concerning the interaction between rootstock type (Freedom and Richter grapevine) and different biofertilizers (Compost, BC, EM and Az) on No. of lateral shoot per transplant, data are recorded in Table (4) it is quite clear from data that, the best result in significantly regarding No. of lateral shoot was obtained with Freedom grape rootstock combined with fertilized with rate "T7" Compost at $75+10 \mathrm{~cm}$ bio-fertilizer (Az) plus $50 \%$ R.D. mineral NPK at rate $(4,3,2) \mathrm{g}$ /transplant in the first and second seasons, respectively. The combination between Richter grapevine rootstock with control treatment had the lowest effect regarding No. of lateral shoot during both seasons of study.

The present result is in harmony with those found by Mostafa (2008) and Seleem-Basma and Telep (2008); El-Sabagh et al., (2011); El-Salhy et al., (2011).

Table 5. Effect of mineral and bio-organic fertilizers on No. of lateral shoot of Crimson grape transplants grafted on both Freedom and Richter rootstocks during both 2018 and 2019 seasons.

\begin{tabular}{|c|c|c|c|c|c|c|}
\hline Parameter & \multicolumn{6}{|c|}{ No. of lateral shoot } \\
\hline Rootstocks & Freedom & Richter & Mean** & Freedom & Richter & Mean** \\
\hline & \multicolumn{3}{|c|}{ First season; 2018} & \multicolumn{3}{|c|}{ Second season; 2019} \\
\hline T1. Control (R.D) NPK at rate $(8,6,4 \mathrm{~g})$. & $10.00 \mathrm{f}$ & $5.00 \mathrm{j}$ & $7.50 \mathrm{C}$ & $8.00 \mathrm{~h}$ & $6.00 \mathrm{j}$ & $7.00 \mathrm{~F}$ \\
\hline $\mathrm{T} 2.50 \%$ control at rate $(4,3,2)+25 \mathrm{~g}$ compost. & $13.00 \mathrm{c}$ & $6.00 \mathrm{i}$ & $9.50 \mathrm{~B}$ & $14.00 \mathrm{c}$ & $5.00 \mathrm{k}$ & $9.50 \mathrm{D}$ \\
\hline T3. $50 \%$ control at rate $(4,3,2)+50$ g compost. & $11.00 \mathrm{e}$ & $9.00 \mathrm{~g}$ & $10.00 \mathrm{~B}$ & $12.00 \mathrm{~d}$ & $10.00 \mathrm{f}$ & $11.00 \mathrm{C}$ \\
\hline T4. $50 \%$ control at rate $(4,3,2)+75$ g compost. & $15.00 \mathrm{~b}$ & $12.00 \mathrm{~d}$ & $13.50 \mathrm{~A}$ & $15.00 \mathrm{~b}$ & $11.00 \mathrm{e}$ & 13.00B \\
\hline $\begin{array}{l}\text { T5. } 50 \% \text { control at rate }(4,3,2)+25 \mathrm{~g} \text { compost }+10 \mathrm{~cm} \\
\text { bio fertilizer }(\mathrm{BC}) .\end{array}$ & $13.00 \mathrm{c}$ & $13.00 \mathrm{c}$ & $13.00 \mathrm{~A}$ & $14.00 \mathrm{c}$ & $14.00 \mathrm{c}$ & $14.00 \mathrm{~A}$ \\
\hline $\begin{array}{l}\text { T6. } 50 \% \text { control at rate }(4,3,2)+50 \mathrm{~g} \text { compost }+10 \mathrm{~cm} \\
\text { bio fertilizer }(\mathrm{EM}) .\end{array}$ & $8.00 \mathrm{~h}$ & $6.00 \mathrm{i}$ & $7.00 \mathrm{C}$ & $9.00 \mathrm{~g}$ & $7.00 \mathrm{i}$ & $8.00 \mathrm{E}$ \\
\hline $\begin{array}{l}\text { T7. } 50 \% \text { control at rate }(4,3,2)+75 \mathrm{~g} \text { compost }+10 \mathrm{~cm} \\
\text { bio fertilizer (AZ). }\end{array}$ & $18.00 \mathrm{a}$ & $8.00 \mathrm{~h}$ & $13.00 \mathrm{~A}$ & $17.00 \mathrm{a}$ & $11.00 \mathrm{e}$ & $14.00 \mathrm{~A}$ \\
\hline $\begin{array}{l}\text { Mean* } \\
\end{array}$ & $12.57 \mathrm{~A}$ & $8.43 \mathrm{~B}$ & & $12.71 \mathrm{~A}$ & $9.14 \mathrm{~B}$ & \\
\hline
\end{tabular}

* and ** means refer to specific effect of root stock type and different treatments of bio-stimulants soil applied, respectively. Values within the same column or row for any of two investigated factors followed by the same letter/s were not significantly at $5 \%$ level where capital letter/s, were used for distinguishing specific effect value of each investigated factor but small letters for interaction of their combination.

\section{- Average leaf area $\left(\mathrm{cm}^{2}\right)$}

The average leaf area of crimson grape was estimated in $\mathrm{cm}^{2}$ in relation to the specific effect of rootstock type (Freedom and Richter) and the different fertilization (Compost, BC, EM and Az), in addition to the interaction effect of their combination.

\section{A. Specific effect:}

Regarding the specific effect of the rootstock type (Freedom and Richter rootstocks) and different fertilization (Compost, BC, EM and Az) beside the control on the average leaf area $\left(\mathrm{cm}^{2}\right)$ of crimson grape, data in Table (6) revealed that, Freedom rootstock had a greater value of leaf area (62.45 and $\left.61.93 \mathrm{~cm}^{2}\right)$ than the other investigated rootstock (Richter) $\left(62.18\right.$ and $\left.60.51 \mathrm{~cm}^{2}\right)$ during both seasons of study, respectively.

Regarding the specific effect of different fertilization (bio and organic fertilizer) on average leaf area $\left(\mathrm{cm}^{2}\right)$, data presented in Table (6), indicated that all the investigated fertilization significantly increased average leaf area $\left(\mathrm{cm}^{2}\right)$ of Crimson grape as compared with "T4" $50 \%$ control at rate $(4,3,2)+75$ g compost $g$ per transplant $\left(65.69\right.$ and $\left.64.79 \mathrm{~cm}^{2}\right)$. Control fertilization treatment gave the lowest value of the average leaf area $\left(\mathrm{cm}^{2}\right)$ in both seasons of study.

\section{B. Interaction effect:}

Concerning the interaction effect of the two investigated factors i.e., rootstock type (Freedom and Richter rootstocks) and different fertilization (Compost, $\mathrm{BC}, \mathrm{EM}$ and $\mathrm{Az})$ on average leaf area $\left(\mathrm{cm}^{2}\right)$ of Crimson grape transplants presented in Table (6) showed variable response of the two rootstocks to the different combination of fertilization treatments.

The most increment of leaf area was that combination between Freedom grapevine rootstock and the lowest fertilization rate (Compost at $25 \mathrm{~g}+10$ cm "BC" $+50 \%$ (R.D.) NPK at rate 4, 3, 2 g per transplant). On the other hand, the lowest value in the average of leaf area was detected by Crimson grape on Richter rootstock and control treatment during both seasons of study. The other combinations were in between.

The obtained result is confirmed by those previously mentioned by Fathi et al., (2002); EissaFawzia et al., (2007 b); Seleem-Basma and Telep (2008); El-Sabagh et al., (2011); El-Salhy et al., (2011) and Abd El Aal et al., (2019). 
Table 6. Effect of mineral and bio-organic fertilizers on leaf area $(\mathrm{cm} 2)$ of Crimson grape transplants grafted on both Freedom and Richter rootstocks during both 2018 and 2019 seasons.

\begin{tabular}{|c|c|c|c|c|c|c|}
\hline \multirow[b]{2}{*}{ Treatments } & \multicolumn{6}{|c|}{ Leaf area $\left(\mathrm{cm}^{2}\right)$} \\
\hline & Freedom & Richter & Mean** & Freedom & Richter & Mean** \\
\hline & \multicolumn{3}{|c|}{ First season; 2018} & \multicolumn{3}{|c|}{ Second season; 2019} \\
\hline T1. Control (R.D) NPK at rate $(8,6,4 \mathrm{~g})$. & $58.0 \mathrm{~g}$ & $54.32 \mathrm{~h}$ & $56.16 \mathrm{G}$ & $56.30 f$ & $52.90 \mathrm{~g}$ & $54.60 \mathrm{G}$ \\
\hline $\mathrm{T} 2.50 \%$ control at rate $(4,3,2)+25 \mathrm{~g}$ compost. & $62.62 d$ & $61.60 \mathrm{e}$ & $62.11 \mathrm{E}$ & $63.20 \mathrm{~b}$ & $60.63 d$ & $61.92 \mathrm{D}$ \\
\hline T3. $50 \%$ control at rate $(4,3,2)+50$ g compost. & $64.11 \mathrm{c}$ & $63.83 \mathrm{c}$ & $63.97 \mathrm{C}$ & $65.27 \mathrm{a}$ & $60.77 \mathrm{~d}$ & $63.02 \mathrm{C}$ \\
\hline $\mathrm{T} 4.50 \%$ control at rate $(4,3,2)+75 \mathrm{~g}$ compost. & $66.17 \mathrm{a}$ & $65.20 \mathrm{~b}$ & $65.69 \mathrm{~A}$ & $65.90 \mathrm{a}$ & $63.68 b$ & $64.79 \mathrm{~A}$ \\
\hline $\begin{array}{l}\text { T5. } 50 \% \text { control at rate }(4,3,2)+25 \mathrm{~g} \text { compost }+10 \mathrm{~cm} \\
\text { bio fertilizer }(\mathrm{BC}) \text {. }\end{array}$ & $58.62 \mathrm{~g}$ & $66.93 \mathrm{a}$ & $62.78 \mathrm{D}$ & $56.80 \mathrm{f}$ & $65.20 \mathrm{a}$ & $61.00 \mathrm{E}$ \\
\hline $\begin{array}{l}\text { T6. } 50 \% \text { control at rate }(4,3,2)+50 \mathrm{~g} \text { compost }+10 \mathrm{~cm} \\
\text { bio fertilizer }(\mathrm{EM}) \text {. }\end{array}$ & $61.44 \mathrm{e}$ & $59.92 \mathrm{f}$ & $60.68 \mathrm{~F}$ & $60.77 d$ & $58.30 \mathrm{e}$ & $59.54 \mathrm{~F}$ \\
\hline $\begin{array}{l}\text { T7. } 50 \% \text { control at rate }(4,3,2)+75 \mathrm{~g} \text { compost }+10 \mathrm{~cm} \\
\text { bio fertilizer (AZ). }\end{array}$ & $66.18 \mathrm{a}$ & $63.48 \mathrm{~cd}$ & $64.83 B$ & $65.30 \mathrm{a}$ & $62.10 \mathrm{c}$ & $63.70 \mathrm{~B}$ \\
\hline
\end{tabular}

* and ** means refer to specific effect of root stock type and different treatments of bio-stimulants soil applied, respectively. Values within the same column or row for any of two investigated factors followed by the same letter/s were not significantly at $5 \%$ level where capital letter/s, were used for distinguishing specific effect value of each investigated factor but small letters for interaction of their combination.

\section{- Root length (cm).}

Data during 2018 and 2019 seasons concerning the specific and interaction effects of the two investigated factors on root length of grape are tabulated in Table (7).

\section{A. Specific effect:}

Referring the specific effect of rootstock type on root length $(\mathrm{cm})$ data in Table (7) revealed that, Freedom rootstock was greater than the other investigated rootstock (Richter) $(81.95$ and $82.69 \mathrm{~cm})$ in both seasons, respectively in this respect.
Concerning the specific effect of the different biostimulants (Compost, BC, EM and Az) on Crimson grape root length, data tabulated in Table (7) showed that, fertilizer with "T4" $50 \%$ control at rate $(4,3,2)$ $+75 \mathrm{~g}$ compost $\mathrm{g} /$ transplant was superior $(98.07 \&$ $95.23 \mathrm{~cm}$ ) in both seasons, respectively, where it was able to increase significantly root length as compared with the different investigated fertilization (Compost, $\mathrm{BC}, \mathrm{EM}$ and $\mathrm{Az}$ ) during both seasons of study.

Table 7. Effect of mineral and bio-organic fertilizers on root length $(\mathrm{cm})$ of Crimson grape transplants grafted on both Freedom and Richter rootstocks during both 2018 and 2019 seasons.

\begin{tabular}{|c|c|c|c|c|c|c|}
\hline Parameter & \multicolumn{6}{|c|}{ Root length $(\mathrm{cm})$} \\
\hline Rootstocks & Freedom & Richter & Mean** & Freedom & Richter & Mean** \\
\hline & \multicolumn{3}{|c|}{ First season; 2018} & \multicolumn{3}{|c|}{ Second season; 2019} \\
\hline T1. Control (R.D) NPK at rate $(8,6,4 \mathrm{~g})$. & $49.51 \mathrm{~g}$ & $47.97 \mathrm{~g}$ & $48.74 \mathrm{~F}$ & $45.40 \mathrm{j}$ & $43.20 \mathrm{k}$ & $44.30 \mathrm{~F}$ \\
\hline $\mathrm{T} 2.50 \%$ control at rate $(4,3,2)+25 \mathrm{~g}$ compost. & $85.46 \mathrm{c}$ & $80.43 \mathrm{e}$ & $82.95 \mathrm{D}$ & $83.10 f g$ & $81.00 \mathrm{~h}$ & $82.05 \mathrm{DE}$ \\
\hline T3. $50 \%$ control at rate $(4,3,2)+50$ g compost. & $85.10 \mathrm{~cd}$ & $83.15 \mathrm{~d}$ & 84.13D & $84.46 \mathrm{ef}$ & $82.30 \mathrm{gh}$ & 83.38D \\
\hline T4. $50 \%$ control at rate $(4,3,2)+75$ g compost. & $100.00 \mathrm{a}$ & $96.13 b$ & $98.07 \mathrm{~A}$ & $98.00 \mathrm{~b}$ & $92.45 \mathrm{c}$ & $95.23 \mathrm{~A}$ \\
\hline $\begin{array}{l}\text { T5. } 50 \% \text { control at rate }(4,3,2)+25 \mathrm{~g} \text { compost }+10 \mathrm{~cm} \\
\text { bio fertilizer }(\mathrm{BC}) .\end{array}$ & $80.00 \mathrm{e}$ & $100.20 \mathrm{a}$ & $90.10 \mathrm{C}$ & $82.30 \mathrm{gh}$ & $100.10 \mathrm{a}$ & $91.20 \mathrm{C}$ \\
\hline $\begin{array}{l}\text { T6. } 50 \% \text { control at rate }(4,3,2)+50 \mathrm{~g} \text { compost }+10 \mathrm{~cm} \\
\text { bio fertilizer }(\mathrm{EM}) \text {. }\end{array}$ & $73.50 f$ & $72.92 f$ & $73.21 \mathrm{E}$ & $85.45 \mathrm{de}$ & $76.35 \mathrm{i}$ & $80.90 \mathrm{E}$ \\
\hline $\begin{array}{l}\text { T7. } 50 \% \text { control at rate }(4,3,2)+75 \mathrm{~g} \text { compost }+10 \mathrm{~cm} \\
\text { bio fertilizer (AZ). }\end{array}$ & $100.10 \mathrm{a}$ & $85.04 \mathrm{~cd}$ & $92.57 \mathrm{~B}$ & $100.10 \mathrm{a}$ & $87.04 \mathrm{i}$ & $93.57 \mathrm{~B}$ \\
\hline Mean* & $81.95 \mathrm{~A}$ & $80.83 \mathrm{~B}$ & & $82.69 \mathrm{~A}$ & $80.35 \mathrm{~B}$ & \\
\hline
\end{tabular}

* and ** means refer to specific effect of root stock type and different treatments of bio-stimulants soil applied, respectively. Values within the same column or row for any of two investigated factors followed by the same letter/s were not significantly at $5 \%$ level where capital letter/s, were used for distinguishing specific effect value of each investigated factor but small letters for interaction of their combination.

\section{B. Interaction effect:}

Concerning the interaction effect of the two investigated factors i.e., rootstock type and different bio-stimulant (Compost, BC, EM and $\mathrm{Az}$ ) on grape transplants root length $(\mathrm{cm})$, data represented in Table
(7) show a considerable and statistically effect in both seasons of the study, where the highest root length was obtained with the combination between Crimson grape transplants grafted on Freedom and Richter rootstocks and fertilized with "T4" and "T5" compost 
at $75 \mathrm{~g}$ plus $50 \%$ R.D. and 25 compost $+10 \mathrm{~cm}$ biofertilizer (BC) $\mathrm{g} /$ transplants $(100.0 \& 100.2 \mathrm{~cm})$ in the first season and "T7" and "T5" in the second one; however the lowest value in root length was noticed by Crimson grape grafted on Freedom or Richter rootstocks and fertilizer with mineral element (control) (49.51 \& $47.97 \mathrm{~cm})$ and $(45.40 \& 43.20 \mathrm{~cm})$ during the both seasons, respectively.

The present result is in harmony with those found Dessouky (2002); Fathi et al., (2002); Fayed (2005b); Eissa-Fawzia et al., (2007 b); SeleemBasma and Telep (2008); El-Kady (2011) and Abd El Aal et al., (2019).

- Total weights of fresh and dry plant organs (gm).

The total weights of fresh and dry plant organs of crimson grape was estimated in gm in relation to the specific effect of rootstock type (Freedom and Richter) and the different fertilization (Compost, BC, Az and $\mathrm{EM}$ ), in addition to the interaction effect of their combination.

\section{A. Specific effect:}

Regarding the specific effect of the rootstock type (Freedom and Richter rootstocks) and different fertilization (Compost, BC, EM and EM) beside the control on the total fresh and dry plant organs (gm) of Crimson grape, data in Tables ( 8 \& 9) revealed that, Freedom rootstock had a greater value of total fresh and dry plant organs (gm) (92.25 \& $89.44 \mathrm{gm})$ and $(60.10 \& 57.81 \mathrm{gm})$ than the other investigated rootstock (Richter) (88.74 \& $84.57 \mathrm{gm})$ and (59.08 \& $56.88 \mathrm{gm}$ ) during both seasons of study, respectively.

Regarding the specific effect of different fertilization (bio and organic fertilizer) on total fresh and dry plant organs (gm), data presented in Tables ( 8 \& 9), indicated that all the investigated fertilization significantly increased total fresh and dry plant organs (gm) of Crimson grape as compared with control which was fertilized with $50 \%$ mineral NPK plus compost at $75 \mathrm{~g}$ per transplant (99.07 \& $95.66 \mathrm{gm})$ and $(68.28 \& 65.90$ gm) both during two seasons, respectively. Control fertilization treatment gave the lowest value of the total fresh and dry plant organs (gm) in both seasons of study.

\section{B. Interaction effect:}

Concerning the interaction effect of the two investigated factors i.e., rootstock type (Freedom and Richter rootstocks) and different fertilization (Compost, $\mathrm{BC}, \mathrm{EM}$ and $\mathrm{Az}$ ) on total fresh and dry plant organs (gm) of crimson grape transplants presented in Tables (8 \& 9) showed variable response of the two rootstocks to the different combination of fertilization treatments.

The most increment of total fresh and dry plant organs (gm) were the combination between Freedom grapevine rootstock and the lowest fertilization rate ("T4" Compost at $75 \mathrm{~g}+, 50 \%$ control at rate $(4,3,2)$ $\mathrm{g}$ per transplant). On the other hand, the lowest value in the total fresh and dry plant organs (gm) were detected by crimson grape on Richter rootstock and control treatment during both seasons of study. The other combinations were in between.

The obtained result is confirmed by those previously mentioned by Eissa-Fawzia et al., (2007 b); Seleem-Basma and Telep (2008); El-Sabagh $e t$ al., (2011); El-Salhy et al., (2011) and Abd El Aal et al., (2019).

Table 8. Effect of mineral and bio-organic fertilizers on total fresh weight plant organs ( $\mathrm{g}$ ) of Crimson grape transplants grafted on both Freedom and Richter rootstocks during both 2018 and 2019 seasons.

\begin{tabular}{|c|c|c|c|c|c|c|}
\hline \multirow{3}{*}{ Treatments } & \multicolumn{6}{|c|}{ Total fresh weight transplant organs $(\mathrm{g})$} \\
\hline & Freedom & Richter & Mean** & Freedom & Richter & Mean** \\
\hline & \multicolumn{3}{|c|}{ First season; 2018} & \multicolumn{3}{|c|}{ Second season; 2019} \\
\hline T1. Control (R.D) NPK at rate $(8,6,4 \mathrm{~g})$. & $81.45 \mathrm{j}$ & $85.51 \mathrm{i}$ & $83.48 \mathrm{~F}$ & $77.76 \mathrm{j}$ & $79.85 \mathrm{i}$ & $78.81 \mathrm{E}$ \\
\hline $\mathrm{T} 2.50 \%$ control at rate $(4,3,2)+25 \mathrm{~g}$ compost. & $85.17 \mathrm{i}$ & $87.32 \mathrm{~h}$ & $86.24 \mathrm{E}$ & $81.40 \mathrm{~h}$ & $82.46 \mathrm{gh}$ & 81.93D \\
\hline T3. $50 \%$ control at rate $(4,3,2)+50 \mathrm{~g}$ compost. & $93.29 \mathrm{~d}$ & 92.38de & $92.83 \mathrm{~B}$ & $91.70 \mathrm{c}$ & $87.20 \mathrm{ef}$ & $89.45 \mathrm{~B}$ \\
\hline $\mathrm{T} 4.50 \%$ control at rate $(4,3,2)+75 \mathrm{~g}$ compost. & $106.7 \mathrm{a}$ & $91.50 \mathrm{ef}$ & 99.07A & $103.4 \mathrm{a}$ & $87.92 \mathrm{e}$ & $95.66 \mathrm{~A}$ \\
\hline $\begin{array}{l}\text { T5. } 50 \% \text { control at rate }(4,3,2)+25 \mathrm{~g} \text { compost }+10 \mathrm{~cm} \\
\text { bio fertilizer }(\mathrm{BC}) \text {. }\end{array}$ & $90.76 f$ & $85.48 \mathrm{i}$ & $88.12 \mathrm{D}$ & $90.18 \mathrm{~d}$ & $83.15 \mathrm{~g}$ & $86.66 \mathrm{C}$ \\
\hline $\begin{array}{l}\text { T6. } 50 \% \text { control at rate }(4,3,2)+50 \mathrm{~g} \text { compost }+10 \mathrm{~cm} \\
\text { bio fertilizer }(\mathrm{EM}) \text {. }\end{array}$ & $99.19 b$ & $82.26 \mathrm{j}$ & $90.72 \mathrm{C}$ & $95.33 b$ & $79.46 \mathrm{i}$ & $87.40 \mathrm{C}$ \\
\hline $\begin{array}{l}\text { T7. } 50 \% \text { control at rate }(4,3,2)+75 \mathrm{~g} \text { compost }+10 \mathrm{~cm} \\
\text { bio fertilizer (AZ). }\end{array}$ & $89.21 \mathrm{~g}$ & $96.70 \mathrm{c}$ & $92.96 \mathrm{~B}$ & $86.34 f$ & $91.98 \mathrm{c}$ & 89.16B \\
\hline Mean* & $92.25 \mathrm{~A}$ & $88.74 \mathrm{~B}$ & & $89.44 \mathrm{~A}$ & $84.57 \mathrm{~B}$ & \\
\hline
\end{tabular}

* and ** means refer to specific effect of root stock type and different treatments of bio-stimulants soil applied, respectively. Values within the same column or row for any of two investigated factors followed by the same letter/s were not significantly at $5 \%$ level where capital letter/s, were used for distinguishing specific effect value of each investigated factor but small letters for interaction of their combination. 
Table 9. Effect of mineral and bio-organic fertilizers on total dry weight plant organs (g) of Crimson grape transplants grafted on both Freedom and Richter rootstocks during both 2018 and 2019 seasons.

\begin{tabular}{|c|c|c|c|c|c|c|}
\hline Parameter & \multicolumn{6}{|c|}{ Total dry weight transplant organs $(\mathrm{g})$} \\
\hline \multirow[t]{2}{*}{ Treatments } & Freedom & Richter & Mean** & Freedom & Richter & Mean** \\
\hline & \multicolumn{3}{|c|}{ First season; 2018} & \multicolumn{3}{|c|}{ Second season; 2019} \\
\hline T1. Control (R.D) NPK at rate $(8,6,4 \mathrm{~g})$. & $54.89 \mathrm{~h}$ & $54.24 \mathrm{~h}$ & $54.57 \mathrm{~F}$ & $51.13 \mathrm{f}$ & $51.53 \mathrm{f}$ & $51.33 \mathrm{~F}$ \\
\hline $\mathrm{T} 2.50 \%$ control at rate $(4,3,2)+25$ g compost. & $52.68 \mathrm{i}$ & $57.38 \mathrm{~g}$ & $55.03 \mathrm{~F}$ & $51.33 \mathrm{f}$ & $55.36 \mathrm{e}$ & 53.34E \\
\hline T3. $50 \%$ control at rate $(4,3,2)+50$ g compost. & $62.04 \mathrm{e}$ & $64.34 \mathrm{c}$ & $63.19 B$ & $58.78 \mathrm{~d}$ & $61.14 \mathrm{c}$ & $59.96 \mathrm{C}$ \\
\hline T4. $50 \%$ control at rate $(4,3,2)+75$ g compost. & $73.24 \mathrm{a}$ & $63.31 d$ & $68.28 \mathrm{~A}$ & $71.40 \mathrm{a}$ & $60.41 \mathrm{c}$ & $65.90 \mathrm{~A}$ \\
\hline $\begin{array}{l}\text { T5. } 50 \% \text { control at rate }(4,3,2)+25 \mathrm{~g} \text { compost }+10 \mathrm{~cm} \\
\text { bio fertilizer }(\mathrm{BC}) .\end{array}$ & $54.52 \mathrm{~h}$ & $58.28 f g$ & $56.40 \mathrm{E}$ & $52.01 \mathrm{f}$ & $55.31 \mathrm{e}$ & $53.66 \mathrm{E}$ \\
\hline $\begin{array}{l}\text { T6. } 50 \% \text { control at rate }(4,3,2)+50 \mathrm{~g} \text { compost }+10 \mathrm{~cm} \\
\text { bio fertilizer }(\mathrm{EM}) \text {. }\end{array}$ & $64.51 b c$ & $50.56 \mathrm{j}$ & 57.53D & $61.30 \mathrm{c}$ & $48.98 \mathrm{~g}$ & 55.14D \\
\hline $\begin{array}{l}\text { T7. } 50 \% \text { control at rate }(4,3,2)+75 \mathrm{~g} \text { compost }+10 \mathrm{~cm} \\
\text { bio fertilizer (AZ). }\end{array}$ & $58.80 \mathrm{f}$ & $65.43 b$ & $62.11 \mathrm{C}$ & $58.73 d$ & $65.40 \mathrm{~b}$ & $62.07 \mathrm{~B}$ \\
\hline
\end{tabular}

* and ** means refer to specific effect of root stock type and different treatments of bio-stimulants soil applied, respectively. Values within the same column or row for any of two investigated factors followed by the same letter/s were not significantly at $5 \%$ level where capital letter/s, were used for distinguishing specific effect value of each investigated factor but small letters for interaction of their combination.

\section{2- Effect of rootstock type and different biofertilizers on leaf mineral composition:}

Leaf macro-element (nitrogen, phosphorus and potassium as percentages) and micro-nutrient (Fe, $\mathrm{Zn}$ and $\mathrm{Mn}$ as ppm) contents in response to specific and interaction effects of (Freedom and Rtkhtar rootstocks grape) and the different fertilizers (Compost, BC, EM and $\mathrm{Az}$ ) and their possible combinations between them were investigated. Data obtained during both 2018 and 2019 seasons are presented in Tables (10, $11,12,13,14$ and 15).

\section{1- Leaf nitrogen content.}

\section{A. Specific effect:}

Considering the specific effect of the rootstock type (Freedom and Richter rootstocks) and different fertilization (Compost, BC, EM and EM) beside the control on the $\mathrm{N}(\%)$ of Crimson grape, data in Table (10) obviously that, Richter rootstock had the highest values of $\mathrm{N}(\%)$ than the other investigated rootstock (Freedom) during both seasons of study, respectively.

With respect to the specific effect of different fertilization (bio and organic fertilizer) on $\mathrm{N}(\%)$, data in Table (10), mentioned that all the investigated fertilization significantly increased $\mathrm{N}(\%)$ of Crimson grape as compared with control which was fertilized with "T3 and T4" $50 \%$ mineral NPK plus compost at 50 or $75 \mathrm{~g}$ per transplant in the first season, while "T5" treatment $50 \%$ control at rate $(4,3,2)+25 \mathrm{~g}$ compost $+10 \mathrm{~cm}$ bio fertilizer (BC) in the second one.

Table 10. Effect of mineral and bio-organic fertilizers on nitrogen $(\%)$ of Crimson grape transplants grafted on both Freedom and Richter rootstocks during both 2018 and 2019 seasons.

\begin{tabular}{|c|c|c|c|c|c|c|}
\hline \multirow{3}{*}{ Treatments } & \multicolumn{6}{|c|}{$\mathbf{N}(\%)$} \\
\hline & Freedom & Richter & Mean** & Freedom & Richter & Mean** \\
\hline & \multicolumn{3}{|c|}{ First season; 2018} & \multicolumn{3}{|c|}{ Second season; 2019} \\
\hline T1. Control (R.D) NPK at rate $(8,6,4 g)$. & $1.39 \mathrm{~d}$ & $1.25 \mathrm{e}$ & 1.32D & $1.42 \mathrm{fg}$ & $1.32 \mathrm{~h}$ & $1.37 \mathrm{E}$ \\
\hline $\mathrm{T} 2.50 \%$ control at rate $(4,3,2)+25 \mathrm{~g}$ compost. & $1.59 \mathrm{c}$ & $1.73 b$ & $1.66 \mathrm{~B}$ & $1.44 \mathrm{ef}$ & $1.77 \mathrm{~b}$ & $1.61 C$ \\
\hline T3. $50 \%$ control at rate $(4,3,2)+50$ g compost. & $1.39 \mathrm{~d}$ & $2.08 \mathrm{a}$ & $1.74 \mathrm{~A}$ & $1.43 \mathrm{fg}$ & $2.16 \mathrm{a}$ & $1.80 \mathrm{~B}$ \\
\hline $\mathrm{T} 4.50 \%$ control at rate $(4,3,2)+75 \mathrm{~g}$ compost. & $1.39 \mathrm{~d}$ & $2.08 \mathrm{a}$ & $1.74 \mathrm{~A}$ & $1.51 \mathrm{de}$ & $2.18 \mathrm{a}$ & $1.85 \mathrm{AB}$ \\
\hline $\begin{array}{l}\text { T5. } 50 \% \text { control at rate }(4,3,2)+25 \mathrm{~g} \text { compost }+10 \mathrm{~cm} \\
\text { bio fertilizer }(\mathrm{BC}) .\end{array}$ & $1.29 \mathrm{e}$ & $2.08 \mathrm{a}$ & 1.69B & $1.57 \mathrm{~cd}$ & $2.19 \mathrm{a}$ & $1.88 \mathrm{~A}$ \\
\hline $\begin{array}{l}\text { T6. } 50 \% \text { control at rate }(4,3,2)+50 \mathrm{~g} \text { compost }+10 \mathrm{~cm} \\
\text { bio fertilizer }(\mathrm{EM}) \text {. }\end{array}$ & $1.39 \mathrm{~d}$ & $1.39 \mathrm{~d}$ & $1.39 \mathrm{C}$ & $1.59 \mathrm{c}$ & $1.35 \mathrm{gh}$ & 1.47D \\
\hline $\begin{array}{l}\text { T7. } 50 \% \text { control at rate }(4,3,2)+75 \mathrm{~g} \text { compost }+10 \mathrm{~cm} \\
\text { bio fertilizer }(\mathrm{AZ}) \text {. }\end{array}$ & $1.39 \mathrm{~d}$ & $1.39 \mathrm{~d}$ & 1.39C & $1.63 \mathrm{c}$ & $1.38 \mathrm{f}-\mathrm{h}$ & $1.51 D$ \\
\hline Mean* & 1.40B & $1.71 \mathrm{~A}$ & & 1.51B & 1.76A & \\
\hline
\end{tabular}

* and ** means refer to specific effect of root stock type and different treatments of bio-stimulants soil applied, respectively. Values within the same column or row for any of two investigated factors followed by the same letter/s were not significantly at $5 \%$ level where capital letter/s, were used for distinguishing specific effect value of each investigated factor but small letters for interaction of their combination. 


\section{B. Interaction effect:}

Regarding the interaction effect of the two investigated factors i.e., rootstock type and the different rates of biofertilizers on leaf $\mathrm{N}$ content, data presented in Table (10) clear obviously that the most simulative combination enhanced in leaf $\mathrm{N}$ contents was that combination between Richter grape rootstock and the biofertilizers with (T5; T4 and T3) g/transplant during the two seasons. Moreover, the lowest decrease in leaf $\mathrm{N}$ content was detected by Freedom rootstock biofertilizer with "T5" $50 \%$ control at rate $(4,3,2)+25$ $\mathrm{g}$ compost $+10 \mathrm{~cm}$ bio fertilizer (BC) and "T1" control treatment (mineral element) during 2018 and 2019 seasons. On the other hand, other combinations treatments were in between in this respect.

Such results are in general agreement with Fathi, et al., (2002); Hassan and Abou-Rayya (2003); ElSalhy et al., (2006); El-Sabagh et al., (2011) and Salhy et al., (2011) and Gomaa (2018).

\section{2- Leaf phosphorus content.}

\section{A. Specific effect:}

Table (11) displays that, leaf phosphorus content did not response specifically to the investigated rootstock type. Hence, the statistically differences were in between the two investigated rootstocks (Freedom and Rtkhtar grape) when leaf phosphorus contents were concerned. With respect to the specific effect of the different fertilizers treatments on leaf phosphorus content, data presented in Table (11) revealed that, as the rate $50 \%$ control at rate $(4,3,2)+75 \mathrm{~g}$ compost + $10 \mathrm{~cm}$ bio fertilizer (AZ) and $50 \%$ control at rate (4, $3,2)+50$ g compost $+10 \mathrm{~cm}$ bio fertilizer (EM) $\mathrm{g} /$ transplant fertilizers increased in leaf phosphorus content increased during both seasons of study. On the contrary, control fertilization treatment gave the lowest value of the phosphorus content in both seasons of study.

\section{B. Interaction effect:}

Results tabulated in Table (11) show the effect of the interaction between rootstock type and the different fertilizer treatments on leaf phosphorus contents. These results revealed that, leaf phosphorus was significantly affected by the interaction between the two investigated factors involved in this study. On the other hand, the highest value of leaf phosphorus content was that combination between Freedom \& Richter rootstock and fertilizer treatments with $\mathrm{T} 7$ " $50 \%$ control at rate $(4,3,2)+75 \mathrm{~g}$ compost $+10 \mathrm{~cm}$ bio fertilizer (AZ)" g/transplant, whereas the lowest value effect on leaf phosphorus content was detected with control treatment combined with fertilizers treatments. Moreover, other combinations were in between in this respect. These results are in congeniality with the findings previously detected by Fayed (2005); Eissa-Fawzia (2007 b); El- Sabagh (2011) and Abd Aal et al., (2019).

Table 11. Effect of mineral and bio-organic fertilizers on phosphorus (\%) of Crimson grape transplants grafted on both Freedom and Richter rootstocks during both 2018 and 2019 seasons.

\begin{tabular}{|c|c|c|c|c|c|c|}
\hline Parameter & \multicolumn{6}{|c|}{$\mathbf{P}(\%)$} \\
\hline Rootstocks & Freedom & Richter & Mean** & Freedom & Richter & Mean** \\
\hline & \multicolumn{3}{|c|}{ First season; 2018} & \multicolumn{3}{|c|}{ Second season; 2019} \\
\hline T1. Control (R.D) NPK at rate $(8,6,4 \mathrm{~g})$ & $0.183 \mathrm{~g}$ & $0.190 \mathrm{~g}$ & 0.187E & $0.191 \mathrm{f}$ & $0.192 \mathrm{f}$ & 0.192E \\
\hline $\mathrm{T} 2.50 \%$ control at rate $(4,3,2)+25 \mathrm{~g}$ compost. & $0.215 f$ & $0.224 \mathrm{ef}$ & $0.220 D$ & $0.219 \mathrm{e}$ & $0.231 \mathrm{de}$ & $0.225 D$ \\
\hline T3. $50 \%$ control at rate $(4,3,2)+50 \mathrm{~g}$ compost. & $0.225 \mathrm{ef}$ & $0.237 \mathrm{e}$ & 0.231D & $0.229 \mathrm{de}$ & $0.242 \mathrm{~d}$ & $0.236 \mathrm{D}$ \\
\hline $\mathrm{T} 4.50 \%$ control at rate $(4,3,2)+75 \mathrm{~g}$ compost. & $0.254 \mathrm{~d}$ & $0.261 \mathrm{~d}$ & $0.258 C$ & $0.261 \mathrm{c}$ & $0.264 \mathrm{c}$ & $0.263 \mathrm{C}$ \\
\hline $\begin{array}{l}\text { T5. } 50 \% \text { control at rate }(4,3,2)+25 \mathrm{~g} \text { compost }+10 \mathrm{~cm} \\
\text { bio fertilizer }(\mathrm{BC}) .\end{array}$ & $0.270 \mathrm{~cd}$ & $0.281 \mathrm{bc}$ & $0.276 B$ & $0.278 \mathrm{bc}$ & $0.283 \mathrm{ab}$ & $0.281 B$ \\
\hline $\begin{array}{l}\text { T6. } 50 \% \text { control at rate }(4,3,2)+50 \mathrm{~g} \text { compost }+10 \mathrm{~cm} \\
\text { bio fertilizer }(\mathrm{EM}) \text {. }\end{array}$ & $0.288 \mathrm{ab}$ & $0.294 \mathrm{ab}$ & $0.291 A$ & $0.291 \mathrm{ab}$ & $0.296 a b$ & $0.294 A$ \\
\hline $\begin{array}{l}\text { T7. } 50 \% \text { control at rate }(4,3,2)+75 \mathrm{~g} \text { compost }+10 \mathrm{~cm} \\
\text { bio fertilizer (AZ). }\end{array}$ & $0.299 \mathrm{a}$ & $0.300 \mathrm{a}$ & $0.300 A$ & $0.300 \mathrm{a}$ & $0.302 \mathrm{a}$ & $0.301 \mathrm{~A}$ \\
\hline Mean* & $0.248 A$ & $0.255 A$ & & $0.253 A$ & $0.259 A$ & \\
\hline
\end{tabular}

* and ** means refer to specific effect of root stock type and different treatments of bio-stimulants soil applied, respectively. Values within the same column or row for any of two investigated factors followed by the same letter/s were not significantly at $5 \%$ level where capital letter/s, were used for distinguishing specific effect value of each investigated factor but small letters for interaction of their combination.

\section{3- Leaf potassium content.}

\section{A. Specific effect:}

Considering the specific effect of the rootstock type (Freedom and Richter rootstocks) and different fertilization (Compost, BC, EM and EM) beside the control on the $\mathrm{K}$ content of Crimson grape, data in Table (10) obviously that, Richter rootstock had the highest values of $\mathrm{K}$ content than the other investigated rootstock (Freedom) during both seasons of study, respectively.

With respect to the specific effect of different fertilization (bio and organic fertilizer) on $\mathrm{K}$ content, data in Table (10), mentioned that all the investigated fertilization significantly increased $\mathrm{K}$ content of Crimson grape as compared with control which was fertilized with "T3 and T5" $50 \%$ mineral NPK plus compost at 50 or compost at $25 \mathrm{~g}+10 \mathrm{~cm}$ bio fertilizer 
(BC) per transplant in the first and second seasons, respectively.

\section{B. Interaction effect:}

Concerning the interaction effect of the two investigated factors i.e., rootstock type and the different rates of fertilizers on leaf $\mathrm{K}$ content, data presented in Table (12) show obviously that, the most spurious combination enhanced leaf $\mathrm{K}$ contents was that combination between Richter grape rootstock and the fertilizers with T5 $(50 \%$ control at rate $(4,3,2)+$ $25 \mathrm{~g}$ compost $+10 \mathrm{~cm}$ bio fertilizer $(\mathrm{BC}) /$ transplant and $\mathrm{EM}$ at $30 \mathrm{~g} /$ transplant treatments during the two seasons respectively. Moreover, the lowest decrease in leaf $\mathrm{K}$ content was detected by Richter grape rootstock fertilizers with control transplants treatment during 2018 and 2019 seasons. On the other hand, other combinations treatments were in between in this respect.

The present results are in partial agreement with the findings of Mengel and Arneke (1982); ElAkkad (2004); Ahmed-Ebtsam et al., (2008); Gawad et al., (2012) and Khalil (2012).

Table 12. Effect of mineral and bio-organic fertilizers on potassium (\%) of Crimson grape transplants grafted on both Freedom and Richter rootstocks during both 2018 and 2019 seasons.

\begin{tabular}{|c|c|c|c|c|c|c|}
\hline Parameter & \multicolumn{6}{|c|}{$\mathrm{K}(\%)$} \\
\hline Rootstocks & Freedom & Richter & Mean** & Freedom & Richter & Mean** \\
\hline & \multicolumn{3}{|c|}{ First season; 2018} & \multicolumn{3}{|c|}{ Second season; 2019} \\
\hline T1. Control (R.D) NPK at rate $(8,6,4 \mathrm{~g})$. & $0.40 \mathrm{k}$ & $0.45 \mathrm{j}$ & $0.42 F$ & $0.36 \mathrm{j}$ & $0.45 \mathrm{~h}$ & $0.41 F$ \\
\hline $\mathrm{T} 2.50 \%$ control at rate $(4,3,2)+25 \mathrm{~g}$ compost. & $0.49 \mathrm{~h}$ & $0.47 \mathrm{i}$ & $0.48 E$ & $0.51 \mathrm{~g}$ & $0.45 \mathrm{~h}$ & $0.48 E$ \\
\hline T3. $50 \%$ control at rate $(4,3,2)+50 \mathrm{~g}$ compost. & $0.87 \mathrm{~d}$ & $0.89 \mathrm{c}$ & $0.88 \mathrm{~A}$ & $0.76 \mathrm{c}$ & $0.77 \mathrm{c}$ & $0.77 \mathrm{~B}$ \\
\hline T4. $50 \%$ control at rate $(4,3,2)+75$ g compost. & $0.67 \mathrm{e}$ & 0.341 & $0.51 D$ & $0.76 \mathrm{c}$ & $0.38 \mathrm{i}$ & $0.57 \mathrm{C}$ \\
\hline $\begin{array}{l}\text { T5. } 50 \% \text { control at rate }(4,3,2)+25 \mathrm{~g} \text { compost }+10 \mathrm{~cm} \\
\text { bio fertilizer }(\mathrm{BC}) \text {. }\end{array}$ & $0.53 \mathrm{~g}$ & $1.18 \mathrm{a}$ & $0.86 B$ & $0.58 \mathrm{e}$ & $1.16 \mathrm{a}$ & $0.87 A$ \\
\hline $\begin{array}{l}\text { T6. } 50 \% \text { control at rate }(4,3,2)+50 \mathrm{~g} \text { compost }+10 \mathrm{~cm} \\
\text { bio fertilizer }(\mathrm{EM}) \text {. }\end{array}$ & $0.30 \mathrm{~m}$ & $0.63 \mathrm{f}$ & $0.47 E$ & $0.34 \mathrm{k}$ & $0.71 \mathrm{~d}$ & $0.53 D$ \\
\hline $\begin{array}{l}\text { T7. } 50 \% \text { control at rate }(4,3,2)+75 \mathrm{~g} \text { compost }+10 \mathrm{~cm} \\
\text { bio fertilizer }(\mathrm{AZ}) \text {. }\end{array}$ & $0.47 \mathrm{i}$ & $1.13 \mathrm{~b}$ & $\mathbf{0 . 8 0 C}$ & $0.55 \mathrm{f}$ & $0.98 b$ & $0.77 B$ \\
\hline Mean* & 0.53B & 0.73A & & $0.55 B$ & 0.70A & \\
\hline
\end{tabular}

* and ** means refer to specific effect of root stock type and different treatments of bio-stimulants soil applied, respectively. Values within the same column or row for any of two investigated factors followed by the same letter/s were not significantly at $5 \%$ level where capital letter/s, were used for distinguishing specific effect value of each investigated factor but small letters for interaction of their combination.

\section{4- Leaf iron content.}

\section{A. Specific effect:}

Referring the specific effect of rootstock type on leaf Fe content of crimson grape as a scion and the two investigated rootstocks respectively, data obtained in Table (13) clearly show that leaf Fe content was not significantly affect of the two investigated rootstocks in the first season. Whereas, leaf Fe content was greatly affected by rootstock type. Leaf Fe content of Freedom rootstock was statistically higher than that recorded with Richter grape rootstock in the second season.

As for the specific effect of the fertilizers on leaf Fe content, data presented in Table (13) revealed that leaf $\mathrm{Fe}$ content took the same trend, whereas the highest leaf $\mathrm{Fe}$ content was remarked with the rootstocks bio-fertilized with $50 \%$ NPK plus $75 \mathrm{~g}$ compost $+10 \mathrm{~cm}$ bio fertilizer (AZ) treatment. Meanwhile, the lowest value of Fe content in leaf $\mathrm{Fe}$ content was associated with the untreated treatment (control) during 2018 and 2019 seasons, respectively.

\section{B. Interaction effect:}

As for the interaction effect of the two investigated factors i.e., rootstock types and the biofertilization on leaf Fe content, data tabulated in Table (13) showed obviously the variable response to the different combinations during 2018 and 2019 seasons. Freedom grape rootstock combined with $50 \%$ control at rate $(4,3,2)+75 \mathrm{~g}$ compost $+10 \mathrm{~cm}$ bio fertilizer (AZ) $\mathrm{g} /$ transplant was the best combination where it raised leaf $\mathrm{Fe}$ content to the maximum level as compared with the other tested combinations during both seasons of study. On the other hand, leaf Fe content reached the minimum value when Freedom and Richter grapes as rootstocks and with control treatment. The other combinations were in between during both seasons of study. 
Table 13. Effect of mineral and bio-organic fertilizers on Fe (ppm) of Crimson grape transplants grafted on both Freedom and Richter rootstocks during both 2018 and 2019 seasons.

\begin{tabular}{|c|c|c|c|c|c|c|}
\hline Parameter & \multicolumn{6}{|c|}{$\mathrm{Fe}(\mathrm{ppm})$} \\
\hline Rootstocks & Freedom & Richter & Mean** & Freedom & Richter & Mean** \\
\hline & \multicolumn{3}{|c|}{ First season; 2018} & \multicolumn{3}{|c|}{ Second season; 2019} \\
\hline T1. Control (R.D) NPK at rate $(8,6,4 \mathrm{~g})$. & $141.0 \mathrm{n}$ & $149.0 \mathrm{~m}$ & $145.0 G$ & $142.0 \mathrm{k}$ & 138.01 & $140.0 G$ \\
\hline $\mathrm{T} 2.50 \%$ control at rate $(4,3,2)+25$ g compost. & $173.0 \mathrm{k}$ & 153.01 & $163.0 \mathrm{~F}$ & $189.0 \mathrm{i}$ & $140.0 \mathrm{kl}$ & $164.5 \mathrm{~F}$ \\
\hline T3. $50 \%$ control at rate $(4,3,2)+50$ g compost. & $189.0 \mathrm{i}$ & $177.0 \mathrm{j}$ & 183.0E & 203.0h & $163.0 \mathrm{j}$ & 183.0E \\
\hline T4. $50 \%$ control at rate $(4,3,2)+75 \mathrm{~g}$ compost. & $203.0 \mathrm{~g}$ & $199.0 \mathrm{~h}$ & 201.0D & 217.0f & $210.0 \mathrm{~g}$ & 213.5D \\
\hline $\begin{array}{l}\text { T5. } 50 \% \text { control at rate }(4,3,2)+25 \mathrm{~g} \text { compost }+10 \mathrm{~cm} \\
\text { bio fertilizer }(\mathrm{BC}) \text {. }\end{array}$ & 226.0f & $236.0 \mathrm{~d}$ & 231.0C & $250.0 \mathrm{e}$ & $270.0 \mathrm{~d}$ & $260.0 \mathrm{C}$ \\
\hline $\begin{array}{l}\text { T6. } 50 \% \text { control at rate }(4,3,2)+50 \mathrm{~g} \text { compost }+10 \mathrm{~cm} \\
\text { bio fertilizer }(\mathrm{EM}) \text {. }\end{array}$ & $230.0 \mathrm{e}$ & $250.0 \mathrm{c}$ & 240.0B & $248.0 \mathrm{e}$ & $278.0 \mathrm{c}$ & 263.0B \\
\hline $\begin{array}{l}\text { T7. } 50 \% \text { control at rate }(4,3,2)+75 \mathrm{~g} \text { compost }+10 \mathrm{~cm} \\
\text { bio fertilizer (AZ). }\end{array}$ & $294.0 \mathrm{a}$ & $283.0 \mathrm{~b}$ & 288.5A & $325.0 \mathrm{a}$ & $288.0 \mathrm{~b}$ & 306.5A \\
\hline Mean* & 208.0A & $206.7 B$ & & 224.9A & 212.4B & \\
\hline
\end{tabular}

* and ** means refer to specific effect of root stock type and different treatments of bio-stimulants soil applied, respectively. Values within the same column or row for any of two investigated factors followed by the same letter/s were not significantly at $5 \%$ level where capital letter/s, were used for distinguishing specific effect value of each investigated factor but small letters for interaction of their combination.

\section{5- Leaf zinc content.}

\section{A. Specific effect:}

Regarding the specific effect of rootstock type (Freedom and Richter grape) and fertilizers (Compost, $\mathrm{BC}, \mathrm{EM}$ and $\mathrm{Az}$ ) on leaf zinc content of Crimson grape content of both investigated rootstocks, data in Table (14) clearly show that there was high significant differences between two rootstocks under study in leaf zinc content of Crimson either grafting on Freedom or Richter grapes rootstocks. Richter grape rootstock was the highest significant value during both seasons of study.

Concerning the specific effect of the fertilizers on leaf zinc content, data presented in Table (14) revealed that as the fertilizers treatment $\mathrm{T} 7(50 \%$ control at rate $(4,3,2)+75 \mathrm{~g}$ compost $+10 \mathrm{~cm}$ bio fertilizer (AZ) the highest value in leaf zinc significantly increased during the two seasons of study.

\section{B. Interaction effect:}

As for the interaction effect of the two investigated factors i.e., rootstock type and the fertilizers on leaf zinc content of Crimson as a scion of Freedom and Richter grape rootstocks. Data tabulated in Table (14) obviously clear that the highest leaf zinc content was coupled with Richter grape rootstock fertilized with $50 \%$ control at rate $(4$, $3,2)+75 \mathrm{~g}$ compost $+10 \mathrm{~cm}$ bio fertilizer (AZ) $\mathrm{g} /$ transplant. On the contrary the lowest value of both rootstocks in leaf zinc content was detected by using Freedom grape as a rootstock fertilized control treatment (mineral element) during both seasons of study.

Table 14. Effect of mineral and bio-organic fertilizers on $\mathrm{Zn}(\mathrm{ppm})$ of Crimson grape transplants grafted on both Freedom and Richter rootstocks during both 2018 and 2019 seasons.

\begin{tabular}{|c|c|c|c|c|c|c|}
\hline \multirow[t]{3}{*}{ Parameter } & \multicolumn{6}{|c|}{$\mathrm{Zn}(\mathrm{ppm})$} \\
\hline & Freedom & Richter & Mean** & Freedom & Richter & Mean** \\
\hline & \multicolumn{3}{|c|}{ First season: 2018} & \multicolumn{3}{|c|}{ Second season; 2019} \\
\hline T1. Control (R.D) NPK at rate $(8,6,4 \mathrm{~g})$. & $46.00 \mathrm{f}$ & $59.00 \mathrm{~d}$ & 52.50D & $51.00 \mathrm{~h}$ & $68.00 \mathrm{e}$ & 59.50D \\
\hline $\mathrm{T} 2.50 \%$ control at rate $(4,3,2)+25 \mathrm{~g}$ compost. & $46.00 \mathrm{f}$ & $61.00 \mathrm{~cd}$ & 53.50D & $51.00 \mathrm{~h}$ & $79.00 \mathrm{c}$ & 65.00C \\
\hline T3. $50 \%$ control at rate $(4,3,2)+50 \mathrm{~g}$ compost. & $47.00 \mathrm{f}$ & $64.00 \mathrm{~b}$ & $55.50 \mathrm{C}$ & $55.00 \mathrm{~g}$ & $83.00 \mathrm{~b}$ & $69.00 \mathrm{~B}$ \\
\hline T4. $50 \%$ control at rate $(4,3,2)+75 \mathrm{~g}$ compost. & $39.00 \mathrm{~g}$ & $46.00 \mathrm{f}$ & $42.50 \mathrm{~F}$ & $52.00 \mathrm{~h}$ & $51.00 \mathrm{~h}$ & $51.50 E$ \\
\hline $\begin{array}{l}\text { T5. } 50 \% \text { control at rate }(4,3,2)+25 \mathrm{~g} \text { compost }+10 \mathrm{~cm} \\
\text { bio fertilizer }(\mathrm{BC}) \text {. }\end{array}$ & $41.00 \mathrm{~g}$ & $51.00 \mathrm{e}$ & 46.00E & $61.00 \mathrm{f}$ & $56.00 \mathrm{~g}$ & $58.50 \mathrm{D}$ \\
\hline $\begin{array}{l}\text { T6. } 50 \% \text { control at rate }(4,3,2)+50 \mathrm{~g} \text { compost } 10 \mathrm{~cm} \\
\text { bio fertilizer (EM). }\end{array}$ & $60.00 \mathrm{~d}$ & $63.00 \mathrm{bc}$ & $61.50 \mathrm{~B}$ & $79.00 \mathrm{c}$ & $60.00 f$ & 69.50B \\
\hline $\begin{array}{l}\text { T7. } 50 \% \text { control at rate }(4,3,2)+75 \mathrm{~g} \text { compost }+10 \mathrm{~cm} \\
\text { bio fertilizer (AZ). }\end{array}$ & $64.00 \mathrm{~b}$ & $80.00 \mathrm{a}$ & 72.00A & $71.33 \mathrm{~d}$ & $94.00 \mathrm{a}$ & $82.67 \mathrm{~A}$ \\
\hline
\end{tabular}

* and ** means refer to specific effect of root stock type and different treatments of bio-stimulants soil applied, respectively. Values within the same column or row for any of two investigated factors followed by the same letter/s were not significantly at $5 \%$ level where capital letter/s, were used for distinguishing specific effect value of each investigated factor but small letters for interaction of their combination. 


\section{6- Leaf manganese content.}

\section{A. Specific effect:}

Concerning the specific effect of rootstock type on leaf $\mathrm{Mn}$ content of Crimson grape as a scion and the two to examine rootstocks, respectively. Data obtained in Table (15) obviously that leaf Mn content was not affected by any of the two investigated rootstocks during the first season of study. Whereas the second one leaf Mn content was greatly affected by rootstock type. Leaf $\mathrm{Mn}$ content of Freedom rootstock was statistically higher than that recorded with Richter grapevine rootstock.

Regarding the specific effect of the fertilizers on leaf Mn content, data presented in Table (15) clearly that leaf Mn content took the same trend, whereas the highest leaf $\mathrm{Mn}$ content was remarked with the transplants fertilized with Compost, $\mathrm{BC}, \mathrm{EM}+\mathrm{Az}$ at $10 \mathrm{~g} /$ transplant. Meanwhile, the lowest value of $\mathrm{Mn}$ content in leaf was associated with the control treatment (mineral fertilizer) during 2018 and 2019 seasons, respectively.

\section{B. Interaction effect:}

Concerning the interaction effect of the two investigated factors i.e., rootstock types and the fertilization on leaf $\mathrm{Mn}$ content, data tabulated in Table (15) showed obviously took the same trend to the different combinations during both seasons. Freedom grapevine rootstock combined with Compost, BC, EM+ Az at $10 \mathrm{~g} /$ transplant treatment was the best combination where it raised leaf $\mathrm{Mn}$ content to the maximum level as compared with the other tested combinations during both seasons of study. On the other hand, leaf Mn content reached the minimum value when Richter grape as rootstock and control treated. The other combinations were in between during both seasons of study.

This trend of response is in general agreement with the findings of El-Akkad (2004) Ahmed-Ebtsam et al., (2008); Gawad et al., (2012); Khalil (2012) and Abd El-Aal (2019).

Table 15. Effect of mineral and bio-organic fertilizers on $\mathrm{Mn}(\mathrm{ppm})$ of Crimson grape transplants grafted on both Freedom and Richter rootstocks during both 2018 and 2019 seasons.

\begin{tabular}{|c|c|c|c|c|c|c|}
\hline Parameter & \multicolumn{6}{|c|}{$\mathrm{Mn}(\mathrm{ppm})$} \\
\hline Rootstocks & Freedom & Richter & Mean** & Freedom & Richter & Mean** \\
\hline & \multicolumn{3}{|c|}{ First season; 2018} & \multicolumn{3}{|c|}{ Second season; 2019} \\
\hline T1. Control (R.D) NPK at rate $(8,6,4 \mathrm{~g})$. & $54.00 \mathrm{i}$ & $58.00 \mathrm{~h}$ & $56.00 \mathrm{~F}$ & $61.00 \mathrm{i}$ & $54.00 \mathrm{j}$ & $57.50 G$ \\
\hline $\mathrm{T} 2.50 \%$ control at rate $(4,3,2)+25 \mathrm{~g}$ compost. & $69.00 \mathrm{~g}$ & $79.00 \mathrm{f}$ & 74.00E & $71.00 \mathrm{~h}$ & $73.00 \mathrm{~g}$ & 72.00F \\
\hline T3. $50 \%$ control at rate $(4,3,2)+50 \mathrm{~g}$ compost. & $70.00 \mathrm{~g}$ & $86.00 \mathrm{e}$ & 78.00D & $76.00 \mathrm{f}$ & $93.00 \mathrm{~d}$ & 84.50E \\
\hline T4. $50 \%$ control at rate $(4,3,2)+75$ g compost. & $86.00 \mathrm{e}$ & $97.00 \mathrm{~d}$ & $91.50 \mathrm{C}$ & $85.00 \mathrm{e}$ & $98.00 \mathrm{c}$ & 91.50D \\
\hline $\begin{array}{l}\text { T5. } 50 \% \text { control at rate }(4,3,2)+25 \mathrm{~g} \text { compost }+10 \mathrm{~cm} \\
\text { bio fertilizer }(\mathrm{BC}) .\end{array}$ & $98.00 \mathrm{~d}$ & $106.0 \mathrm{~b}$ & 102.0B & $99.00 \mathrm{c}$ & $99.00 \mathrm{c}$ & 99.00C \\
\hline $\begin{array}{l}\text { T6. } 50 \% \text { control at rate }(4,3,2)+50 \mathrm{~g} \text { compost }+10 \mathrm{~cm} \\
\text { bio fertilizer }(\mathrm{EM}) \text {. }\end{array}$ & $103.0 \mathrm{c}$ & $109.0 \mathrm{a}$ & 106.0A & $108.0 \mathrm{a}$ & $104.0 \mathrm{~b}$ & 106.0B \\
\hline $\begin{array}{l}\text { T7. } 50 \% \text { control at rate }(4,3,2)+75 \mathrm{~g} \text { compost }+10 \mathrm{~cm} \\
\text { bio fertilizer (AZ). }\end{array}$ & $106.0 \mathrm{~b}$ & $106.0 \mathrm{~b}$ & $106.0 \mathrm{~A}$ & $109.0 \mathrm{a}$ & $108.00 \mathrm{a}$ & $108.50 \mathrm{~A}$ \\
\hline Mean* & 83.71B & 91.57A & & 87.00B & 89.86A & \\
\hline
\end{tabular}

* and ** means refer to specific effect of root stock type and different treatments of bio-stimulants soil applied, respectively. Values within the same column or row for any of two investigated factors followed by the same letter/s were not significantly at $5 \%$ level where capital letter/s, were used for distinguishing specific effect value of each investigated factor but small letters for interaction of their combination.

\section{References}

Abd El-Aal, M.M. and Abd El-Rahman, H.M. (2019). Impact of PGPR and inorganic fertilization on growth and productivity of sweet Ananas melon. International Journal of Agricultural Science and Research (IJASR), 4 (3):11-26.

Ahmed-Ebtsam, A.M.; El-Salhy A.M. and Amin, K.I. (2008). Effect of Bio-fertilization on growth, yield berry quality of some seedless grape cultivars. Assiut J. Agric. Sci., 39(2): 111-129.

Canellas, L. P. and Olivares, F. L. (2019). Physiological responses to Humic substances as plant growth promoter, Chemical and Biological Technologies in Agriculture, 1(3)1-11.
Chapman, H. D. and Pratt, P. F. (1961). Methods of Analysis for Soil, Plant and Waters. Univ. of California Division of Agric. Sci. 6th Ed. Pi 56-64.

Chatzatheodorou, I. T.; Sotiropoulos, T. E. and Mouhtaridou, G. I. (2004). Effect of nitrogen, phosphorus, potassium fertilization and manure on fruit yield and fruit quality of the peach cultivars Spring Time and Red Haven. Agron. Res., 2 (2): 135-143.

Chou, G. J. (1966). A new method of measuring the leaf area of citrus trees. Acta. Hort. Sci, 5: 17-20 (C. F. Hort. Abst. 36:7315).

Dessouky, M. M. M. (2002). A comparative response of Borago officinalis L. plant to the bio- chemical fertilization and Adinosine-TRI-Phosphate (ATP) 
treatments. Bull. Fac. Agric., Cairo Univ., 53: 613638.

Duncan, B. D. (1955). Multiple test rang and multiple F tests. Biometries, II: 1-42.

Duncan, D. B. (1955): Multiple range and multiple F. tests. Biometrics, 11: 1-42.

Eissa-Fawzia, M.; Faith, M.A. and El-Shall, S.A. (2007b). Response of peach and apricot seedling to EM treatments under salinity condition. J. Agric. Sci., Mansoura Univ. 32 (5): 3605-3620.

El-Akkad, M. M. (2004). Physiological studies on vegetative growth and fruit quality in some grapevine cultivars. Ph.D. Thesis, Fac. of Agric., Assiut Univ., Egypt, pp.262.

El-Kady, A.M. (2011). Effect of certain cultural treatments on growth and Productivity of some seedless grape cultivars. Ph.D. Thesis, Fac. Agric. Assiut Univ., Egypt.

El-Sabagh, A.S.; El-Morsy, F.M. and Farag, A.R. (2011). Effect of bio-fertilizers as a partial substitute for nitrogen on vegetative growth, yield, fruit quality and leaf mineral content of two seedless grape cultivars, 1- Vegetative growth and yield. J. of Hort. Sci. \& Orna. 3 (2): 166-175.

El-Sahly, A.M.; Marzouk, H.M.M. and El-Akkad, M.M. (2006). Biofertilization and elemental sulpher effects on growth and fruiting of King Ruby and Red Roomy grapevines. Egypt. J. Hort.; 33: 29-43.

El-Salhy, A.M.; Amen; K.I.A.; Masoud, A.A.B. and Abozeed, E.A. (2011). Response of Ruby Seedless and red roomy grapevines to application of some bio-fertilizers, Assiut J. Agric. Sci., 41(5): 125-142.

Fathi, M. A.; Fawzia-Eissa, M. and Yehia M. M. (2002). Improving growth, yield and fruit quality of "Desert Red" peach and "Anna" Apple by using some bio-stimulants. Minia J Agric Res. \& Dev., 22 (4): 519-534.

Fayed, T.A. (2005 b). Effect of some organic manures and bio-fertilizers on Anna apple trees. A-vegetative growth and leaf chemicals constituents, Egypt. J. Apple. Sci., 20 (1): 159175.

Gawad, S.M.; Abd El-Wahab, S.M., Hassan, F.A. and Abd El-Aziz, A.M. (2012). Effect of some soil conditioners and organic fertilizers on vegetative growth and quality of Crimson seedless grapevines. Journal of Horticultural Science \& Ornamental Plants, 4 (3). 260-266.

Gomaa, E.F. (2018). Effect of Nitrogen, Phosphorus and Bio fertilizers on Quinoa Plant, Journal of Applied Sciences Research, ISSN 1819-544X, 9(8): 5210-5222.

Hassan, H.S.A. and Abou-Rayya, M.S. (2003). Effect of some bio fertilizers on leaf mineral content, yield and fruit quality of Anna apple trees grown under Northern Sinai condition. Egypt. J. Appl. Sci., 18 (8B): 559-574.
Hulme, A.C. (1971). The biochemistry of fruit and their products. Published by Academic Press Landon and New York, Vol. Chap. 2, pp: 65-101.

Idso, S. B.; Idso, K.E.; Garcia, R.L.; Kimball, B.A. and Hoober, J.K. (1995). Effects of atmosphere $\mathrm{CO}_{2}$ enrichment and foliar methanol application on net photosynthesis of sour orange trees (citrus aurantium, Rutaceae) leaves. Amer. J. of Botany 82 (1): 26-30.

Jackson, M.L. (1967). Soil Chemical Analysis. Prentice - Hall. Inc. Englewood Clif., N, I. Library Congress, U. S. A.

Jackson, M.L. and Ulrish, A. (1959). Analytical methods for use in plant analysis. Coll. of Agric. Exp. State Bull. 766: 35 pp.

Johanson, D.V. (1940). Plant micro technique. New York, London, McGrow-Hill Book Co. Inc. PP. 27-154.

Labanauskas, C.K. and Puffer, R.E. (1966). Effect of foliar and application of $\mathrm{Mn}, \mathrm{Zn}$ and Urea on Valencia orange yield and foliage composition. Pro. Amer. Soc. Hort Sci., 86:185-194.

Mahmoud, H.M. and Fatma-Mahmoud, A.F. (1999). Studies on effect of some bio fertilizers on growth of peach seedlings and root rot disease incidence. Egypt. J. Hort. 26 (1): 7-18.

Mengel, K. and Arneke, W.W. (1982). Effect of potassium on the water potential, the pressure potential, the osmotic potential and cell elongation in leaves Phaseoilus vulgaris. Physiol. Plant., 54: 402-408.

Mostafa, R.A.A. (2008). Effect of bio and organic nitrogen fertilization and elemental sulphur application on growth, yield and fruit quality. Assiut J. Agric. Sci., 39 (1): 79-96.

Murphy, J. and Riely, J.P. (1962). A modified single method for the determination of phosphorus in natural water. Anal.Chemi.Acta., 27: 31-36.

Piper, C. S. (1958). Soil and Plant Analysis. Inter. Sci. Publishers. New York, 213-217.

Pregl, E. (1945). Quantitative Organic Micro Analysis. 4th Ed. Chundril, London.

Sahrawat, K.L. (1979). Nitrogen losses in rice soils. Fert. News. 24: 38-48.

Seleem, M. Basma and A.M. Telep (2008). Effect of organic and bio-fertilizers as a partial substitute for inorganic nitrogen in superior grapevines. Minia J. of Agric. Res. \& Develop. 28 (1): 23-35.

Snedecor, G. W. and W. G. Cochran (1977). Statistical Methods, Eight Edition, Iowa State University Press.

Snedecor, G.W. and Cochran, W.G. (1988). Statistical methods. $6^{\text {th }}$ Ed. The Iowa state Univ. Press, Ames., Iowa, U.S.A. pp. 593.

Winkler, A. (1965). General viticulture. Univ. Calif. Press Berkely and Los Angeles.

Wood, C.W.; Tracy, P.W.; Reeves, D.W. and Edmisten, K.L. (1992). Determination of cotton nitrogen status with hand held chlorophyll meter spad 502. J. plant Nutr. 15: 1439-1442. 


\section{تأثير التسميد ونوع الأصل على النمو الخضري والحالة الغذائية لثتلات العنب صنف (الكريمسون) المطعومة أحمد احمد رزق السيد عطوية - فاتن حسن محمود إسماعيل - أميرة سلطان - محمد محي الاين مختار قسم البساتين - كلية الزراعة - جامعة بنها}

أجريت هذه الدراسة خلال موسمين منتاليين هما 2018 و2019 في مشتل قسم البساتين بكلية الزراعة - جامعة بنها على شتلات عنب كريمسون عمرها سنه مطعومة على أصلى ريختر وفريدوم لدراسة استجابة النمو الخضري والحالة الغذائية لهذه الثتلات للتسميد المعدني والحيوي والعضوي. وقد أجريت على الشتلات المعاملات الآتية: 1- تسميد الثتلات (الإضافة الأرضية) بسلفات الامومونيوم والسوبر فوسفات و سلفات البوتاسيوم بمعدل 8 و 6 و 4 جرام لكل شتلة على التوالي ( المقارنة). 2- تسميد الثتلات (إضافة أرضية) بنصف الكمية (50 \%) من سلفات الامومونيوم والسوبر فوسفات وسلفات البوتاسيوم بمعدل 4 و 3 و 2 جرام لكل شتلة + الكمبوست بمعدل 25 جرام لكل شنلة.

3- تسميد الثتلات (إضافة أرضية) بنصف الكمية (50 \%) من سلفات الامومونيوم والسوبر فوسفات وسلفات البوتاسيوم بمعدل 4 و 3 و 2 جرام لكل شتلة + الكمبوست بمعدل 50 جرام لكل شتلة. 4- تسميد الثتلات (إضافة أرضية) بنصف الكمبة (50 \%) من سلفات الامومونيوم والسوبر فوسفات وسلفات البوتاسيوم بمعدل 4 و 3 و 2 جرام لكل شتلة + الكمبوست بمعدل 75 جرام لكل شتلة.

5- تسميد الثتلات (إضافة أرضية) بنصف الكمية (50 \%) من سلفات الامومونيوم والسوبر فوسفات وسلفات البوتاسيوم بمعدل 4 و 3 و 2 جرام لكل شتلة

+ الكمبوست بمعدل 25 جرام لكل شتلة + 10 سم من السماد الحيوي الباسياليس بوليميكس (BC). 6- تسميد الثتلات (إضافة أرضية) بنصف الكمية (50 \%) من سلفات الامومونيوم والسوبر فوسفات وسلفات البوتاسيوم بمعدل 4 و 3 و 2 جرام لكل شتلة + الكمبوست بمعدل 50 جرام لكل شتلة + 10 سم من السماد الحيوي الكائنات الحية الدقيقة (EM). 7- تسميد الثتلات (إضافة أرضية) بنصف الكمية (50 \%) من سلفات الامومونيوم والسوبر فوسفات وسلفات البوتاسيوم بمعدل 4 و 3 و 2 جرام لكل شتلة + الكمبوست بمعدل 50 جرام لكل شتلة + 10 سم من السماد الحيوي الأزوتوباكتركروكوكم (AZ). وقد قست هذه الكميات على ثناث مرات بالنساوي وأضيفت في منتصف مارس و مايو و يوليو في كل موسم من موسمي الدراسة. وتم دراسة استجابة الشتلات للمعاملات المختلفة من خلال القياسات التالية: أولا: قياسات النمو الخضري مثل: ارتفاع الساق - سمك الساق - عدد الأوراق/شتلة - عدد التفرعات - مساحة الورقة - طول الجذر - الوزن الطازج والجاف الكلي لأجزاء الشتلة. ثانيا: الحالة الغذائية (نتروجين، فوسفور بوتاسيوم) و (حديد، زنك ومنجنيز) بالورقة لثتلات العنب الكريمسون المطعومة على أصلى الريختر والفريدوم.

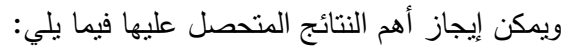
أولا: قياسات النمو الخضري: التأثير النوعي:

أوضحت النتائج المتحصل عليها أن النمو الخضري لشتلات العنب الكريمسون المطعومة على أصل الفريدوم أفضل من الثتلات المطعومة على أصل الريختر خلال موسمي الدراسة. كما أن تسميد شتلات العنب الكريمسون بالمعاملة رقم (4) (تسميد الثتلات (إضافة أرضية) تسميد الثتلات (إضافة أرضية) بنصف الكمية (50 \%) من سلفات الامومونيوم والسوبر فوسفات وسلفات البوتاسيوم بمعدل 4 و3 و 2 جرام لكل شنلة +

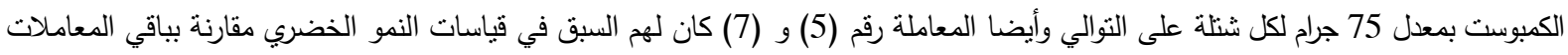
خلال موسمي الدراسة. تأثير التفاعل:

أوضحت النتائج المتحصل عليها أن تسميد شتلات العنب الكريمسون المطعومة على أصل الفريدوم بسلفات الامومونيوم والسوبر فوسفات و سلفات البوناسيوم بمعدل 4 و 3 و 2 جرام لكل شتلة على التوالي (المقارنة) + الكمبوست يتركيزات 75 منفردا، أو 25 + 10 سم من السماد الحيوي (BC). + و الكمبوست بمعل 50 جرام لكل شتلة + 10 سم من السماد الحيوي (AZ) لكل شتلة تعطى أفضل قياسات النمو الخضري بينما اقل القياسات كانت مع شتلات العنب الكريمسون المطعومة على أصل ريختر والمسمدة بسلفات الامومونيوم والسوبر فوسفات و سلفات البوناسيوم بمعدل 4 و 3 و 2 جرام لكل شتلة على التوالي (المقارنة) بينما كانت باقي المعاملات وسطا بينهما. ثانيا: الحالة الغذائية (نتروجين، فوسفور بوتاسيوم) و (حديد، زنك ومنجنيز) بالورقة لثتلات العنب الكريمسون المطعومة على أصلى الريختر والفريدوم.

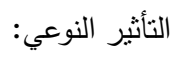


أثنارت النتائج بالنسبة للعناصر الكبرى الثناثة (NPK) لشتلات العنب الكريمسون المطعومة على أصل الريختر أفضل من الثتلات المطعومة على أصل الفريدوم خلال موسمي الدراسة. حيث وجد زيادة معنوية لعنصري البنتروجين والبوتاسيوم لشتلات العنب المطعومة على أصل الريختر مقارنة بالفريدوم، أما بالنسبة لعنصر الفوسفور فلا يوجد زيادة معنوية بين الأصلين المختبرين تحت الدراسة خلال الموسمين على التوالي، كما تباينات النتائج الخاصة بنسميد شتلات العنب الكريمسون بالمعاملة رقم (4) (تسميد الشتلات (إضافة أرضية) تسميد الثتلات (إضافة أرضية) بنصف الكية الكية (50 \%) من سلفات الامومونيوم والسوبر فوسفات وسلفات البوتاسيوم بمعدل 4 و 3 و2 جرام لكل شتلة + الكمبوست بمعدل 75 جرام لكل شتلة على التوالي وأيضا المعاملة رقم (5) و (7) كان لهم السبق في قياسات النمو الخضري مقارنة بباقي المعاملات خلال موسمي الدراسة. أما بالنسبة لتأثير

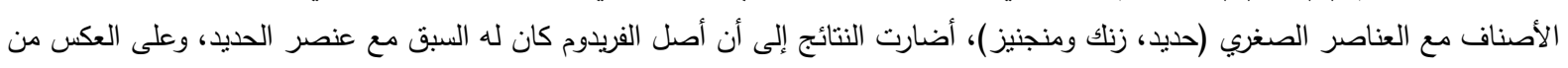

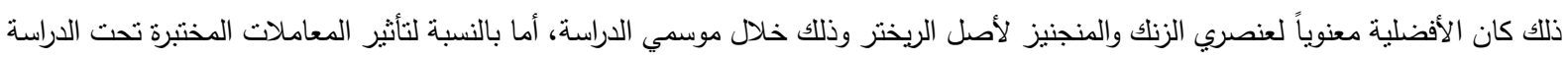

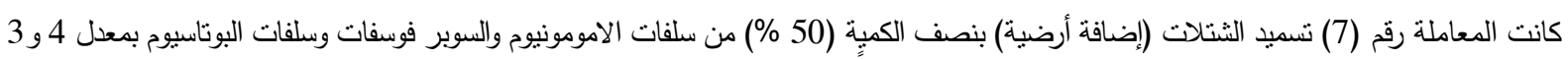
و جرام لكل شتلة + الكمبوست بمعدل 50 جرام لكل شتلة + 10 سم من السماد الحيوي الأزوتوباكتركروكوكم (AZ) هي الأعلى للثلاث عناصر خلاد موسمي الدراسة تأثير التقاعل:

أوضحت النتائج المتحصل عليها أن تسميد شتنات العنب الكريمسون المطعومة على أصل الفريدوم بسلفات الامومونيوم والسوبر فوسفات و سلفات البوتاسيوم بمعدل 4 و 3 و 2 جرام لكل شتلة على التوالي (المقارنة) + الكمبوست ينركيزات 75 منفردا، أو 25 + 10 سم من السماد الحيوي (BC) ( + (BC) لكل شتلة تعطى أفضل قياسات النمو الخضري بينما اقل القياسات كانت مع شتلات العنب الكريمسون المطعومة على أصل ريختز والمسمدة بسلفات الامومونيوم والسوبر فوسفات و سلفات البوتاسيوم بمعدل

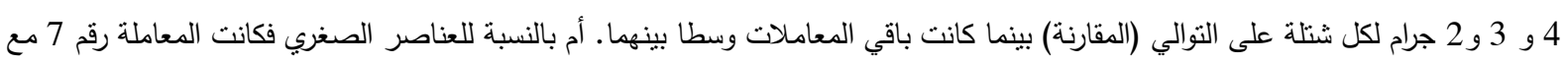
الأصل فريدوم هي الأعلي لعنصر الحديد، أم بالنسبة لعنصري الزنك والمنجنيز فكانت المعاملة رقم (7) مع الأصل الريختر عي الأعلى معنوياً وأيضا المعاملة السادسة بدون وجود زيادة معنوية بينهما وذلك لعنصر المنجنيز خلال موسمي الدراسة. 